\title{
Connessioni tra saperi. Disciplinarietà, interdisciplinarietà e transdisciplinarietà delle scienze grafiche
}

\author{
Enrico Cicalò
}

Abstract

In questo articolo si discute l'evoluzione della discipline focalizzate sulla rappresentazione grafica in relazione al processo di frammentazione del sapere in ambiti sempre più specializzati. La discussione viene condotta attraverso un'analisi della letteratura inerente la storia delle scienze, delle arti e delle discipline accademiche, che conferma il ruolo fondamentale delle conoscenze grafiche nello sviluppo del pensiero e nell'esplorazione in diversi ambiti del sapere. Proprio questo porta le conoscenze grafiche ad essere soggette ad una sorta di diaspora all'interno dei più svariati ambiti disciplinari, che finiscono con l'annettere ai propri corpus metodi tecniche e strumenti propri delle Scienze Grafiche. Dalla discussione delle relazioni e delle connessioni che si sono sviluppate nel tempo tra i saperi, è possibile evidenziare la necessità di conferire riconoscibilità e visibilità alle Scienze Grafiche, oggi difficilmente collocabili all'interno delle classificazioni internazionali dei settori della ricerca, attraverso un percorso transdisciplinare finalizzato a ridisegnare l'identità delle Scienze Grafiche sia internamente, attraverso la definizione dei campi di indagine, sia esternamente, mediante la definizione delle possibili e fertili connessioni con gli altri saperi per poter dare risposte alle domande di ricerca interdisciplinare provenienti dalla società e ridefinire così il loro ruolo all'interno della geografia e della genealogia dei saperi.

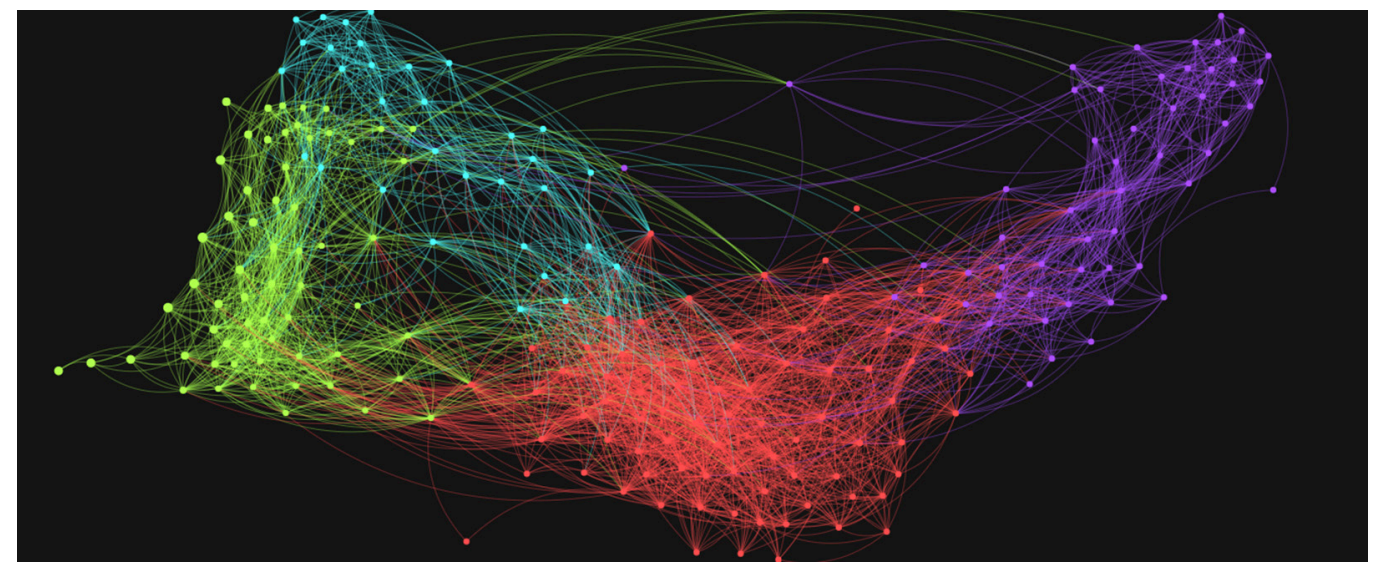




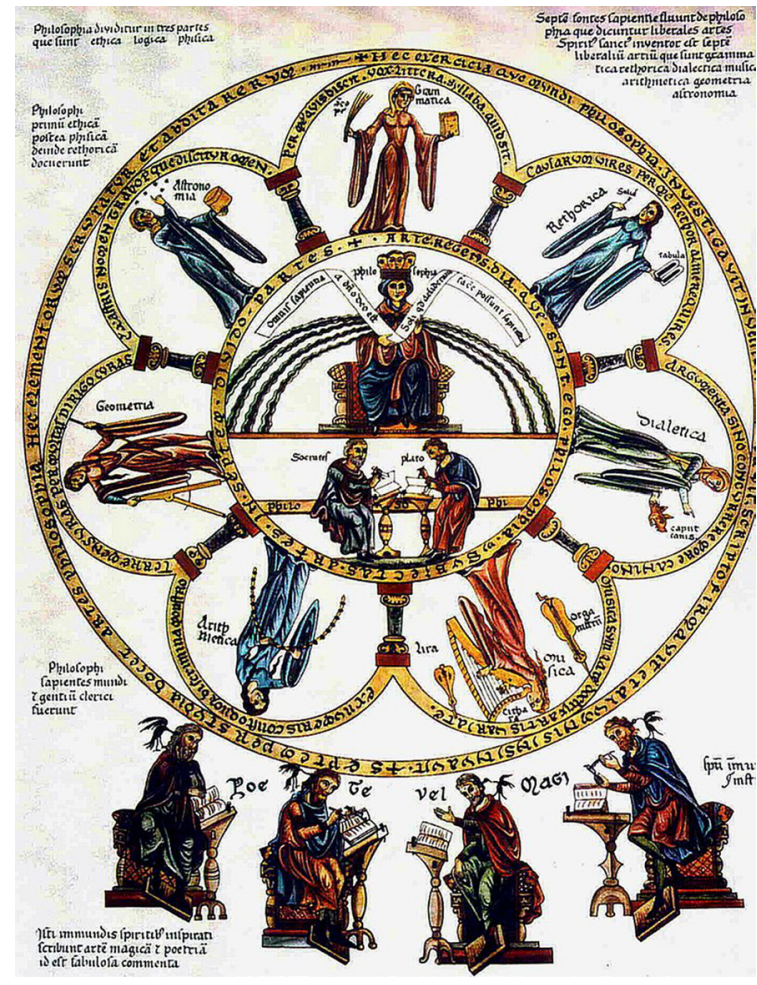

\section{Pre-disciplinarietà}

In principio, in epoca classica, la scienza aveva una natura predisciplinare. Platone, ne La Repubblica, descrive la conoscenza intellegibile come una sfera unitaria, distinguibile solo dalla conoscenza sensibile, indagabile attraverso un approccio esplorativo di matrice filosofica capace di analizzare l'intera sfera della conoscenza. Sarà poi Aristotele, nel libro VI della Metafisica, a ipotizzare una prima suddivisione del sapere in campi di indagine - scienze teoriche, scienze pratiche e scienze poietiche o produttive - inaugurando quella che sarà la tendenza alla suddivisione delle scienze in unità di conoscenza specializzate [Klein Thompson 1990, p. 19] che connoterà la storia delle scienze sino ai nostri giorni. In epoca Romana permarrà la tendenza a frammentare i diversi campi del sapere attraverso la formulazione della distinzione tra arti liberali (trivium articolato in grammatica, retorica e dialettica; e quatrivium articolato in aritmetica, geometria, astronomia e musica) alle quali si contrappongono le arti meccaniche, formalizzate solo in epoca medioevale - lanificium, armatura (ogni lavoro in legno, pietra, metallo, fabbricazione di armi, architettura, scultura, pittura), navigatio (comprendente il commercio), agricultura, venatio, medicina, theatrica. Queste ultime godevano di minore considerazione in quanto ritenute legate a competenze esclusivamente manuali e non intellettuali. Sarà nel Rinascimento che le due competenze si andranno a compenetrare in quelle figure di artisti intellettuali capaci di recuperare una concezione di conoscenza come sfera unitaria. Con l'invenzione della stampa, l'intensificazione dei contatti tra le diverse regioni e lo sviluppo economico, la produzione e la diffusione del sapere subiscono una forte accelerazione che stimola la necessità di archiviare e classificare la conoscenza, aprendo la strada alle discipline, intese come sistemi di produzione e di archiviazione della conoscenza [Stichweh 200 I].

Sarà poi la diffusione dei prodotti editoriali scientifici a favorire la specializzazione delle competenze e la conseguente formazione delle comunità di specialisti, che saranno indispensabili per il funzionamento delle singole discipline [Kuhn 20I2]. In particolare, dopo il 1780, in Francia, Germania e Inghilterra iniziano a circolare le riviste scientifiche specializzate, che divengono non solo un canale di diffusione delle conoscenze disciplinari ma veri e propri 
strumenti per la costruzione delle discipline stesse, attraverso la costruzione delle comunità degli specialisti interessati ai particolari temi esplorati nella rivista. La comunità sceglie dunque una particolare pubblicistica scientifica e allo stesso tempo attraverso essa si specializza ulteriormente [Stichweh 200I].

Se la scienza, secondo la tradizione filosofica classica pre-disciplinare, era finalizzata alla ricerca della verità, nella fase disciplinare è orientata alla ricerca della novità in funzione della stessa pubblicistica scientifica [Stichweh 200 I]. Questa produzione di quantità immani di nuova conoscenza rende impensabile per un singolo studioso confrontarsi con l'intera sfera del sapere rendendo invece necessaria la formazione di ambiti isolati di sapere [Cummings 1989]. La figura di uno studioso capace di confrontarsi trasversalmente con diverse

Fig. 2. Andrea Pisano e collaboratori (1334-1360), Campanile di Giotto, Santa Maria del Fiore, Firenze, Rappresentazione e delle scienze

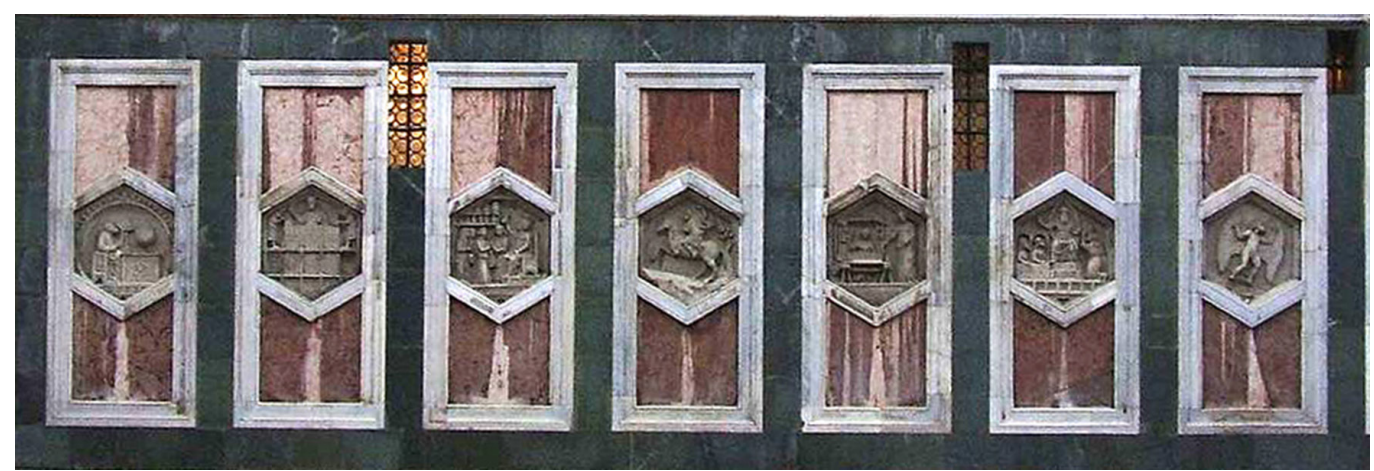

sfere della conoscenza, così come avveniva nella prima antichità classica e nel Rinascimento, non appare dunque più concepibile. Negli ultimi secoli si è concluso così definitivamente il passaggio da un'idea di unitarietà della conoscenza a un'idea di specializzazione della conoscenza [Nissani 1997]. Nella cultura occidentale si è gradualmente accentuata in particolare la divisione tra quelle che Snow definisce "le due culture del sapere" [Snow 20I2], quella umanistica e quella scientifica, contenenti ognuna una moltitudine di culture, ciascuna delle quali delimita il proprio territorio e spesso si rifiuta di dialogare con le altre, causando importanti conseguenze nello sviluppo del pensiero e della ricerca.

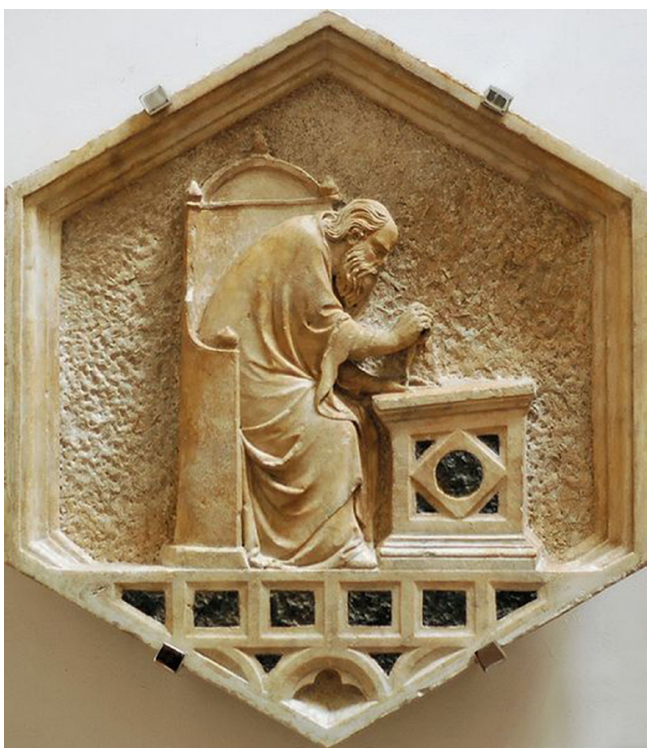




\section{Disciplinarietà}

Come introdotto nel paragrafo precedente, una disciplina può essere definita come un dominio autonomo e isolato dell'esperienza umana in cui ci si riconosce una comunità di esperti [Nissani 1997]. II termine disciplina deriva dal latino discere ed è dunque strettamente legato alla trasmissione della conoscenza allinterno dei diversi percorsi formativi. La disciplina rappresenta dunque un dominio di insegnamento, in genere connesso alle competenze richieste dal mondo del lavoro e delle professioni [Stichweh 200 I].

Secondo Goodland, affinché un campo del sapere possa essere definito 'disciplina' è necessario che vengano rispettati alcuni requisiti [Goodland 1979]:

I) le discipline hanno un particolare soggetto di ricerca, che può anche essere condiviso con altre discipline;

2) le discipline hanno un bagaglio di conoscenze prodotte nel corso del tempo su quel particolare soggetto di ricerca, in questo caso non condiviso con altre discipline;

3) le discipline devono avere teorie e concetti che possono organizzare la conoscenza specialistica prodotta;

4) le discipline usano specifiche terminologie e linguaggi tecnici in relazione ai propri soggetti di ricerca;

5) le discipline hanno metodi di indagine propri;

6) le discipline si formalizzano all'interno delle istituzioni attraverso insegnamenti nei percorsi formativi, all'interno di dipartimenti e associazioni.

Le discipline scientifiche hanno non solo il compito di suddividere il sapere in componenti più facilmente governabili e studiabili, ma anche di consentire alle istituzioni di darsi un'organizzazione più efficiente negli ambiti della ricerca e della didattica [Gass 1979 p. I I9], in coerenza con la tendenza della cultura occidentale orientata alla competizione e al raggiungimento dell'eccellenza [Gusdorf 1979 p. I 47].

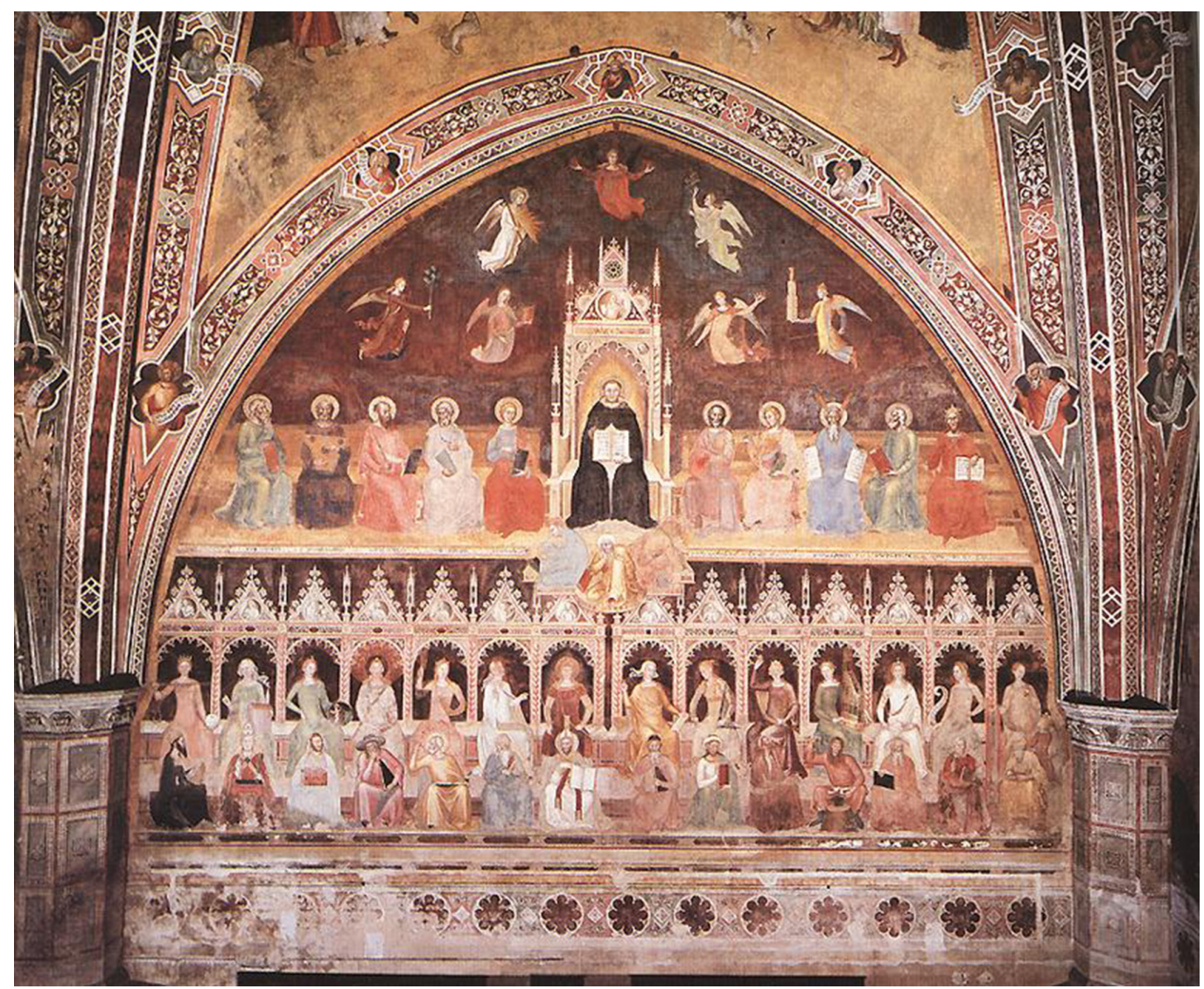




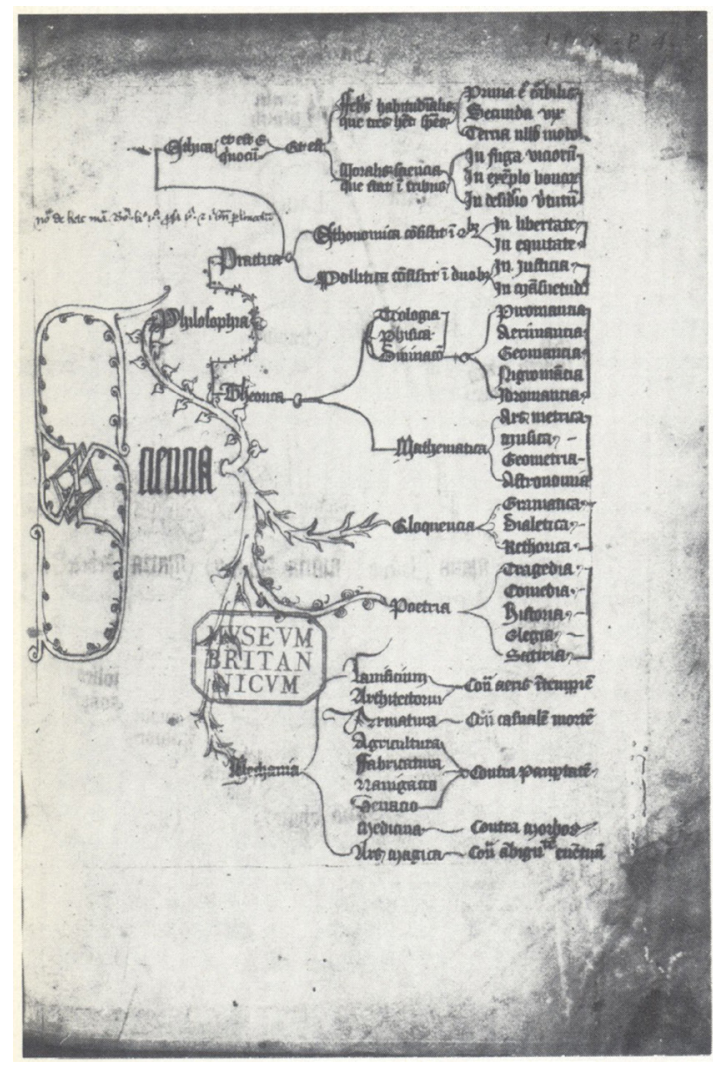

Oltre ad assolvere a compiti meramente classificatori, pratici e organizzativi, le discipline assumono anche un ruolo fondamentale in ambito psico-cognitivo. Howard Gardner ritiene essenziale che in futuro le persone possano essere in grado di pensare nei modi che caratterizzano le maggiori discipline. La mentalità disciplinare viene da lui considerata una delle Cinque chiavi per il futuro oggi più apprezzate e che lo sarà ancora di più in seguito. Essa rientra tra le competenze che governano la sfera dei processi cognitivi così come quella dell'iniziativa umana [Gardner 20I5]. L'intelligenza disciplinare, scrive Gardner, governa una forma di pensiero e deve essere considerata come la modalità conoscitiva che caratterizza una particolare disciplina, un certo mestiere o una data professione. Secondo Gardner una disciplina rappresenta una sfera di competenze e allo stesso tempo un modo peculiare di guardare il mondo. Senza discipline non può esserci interdisciplinarietà [Aldrich 20 I 4]. L'interdisciplinarietà necessita di discipline forti con altrettanto forti metodi, tecniche, strumenti, tradizioni storiche, apparati teorico-culturali.

\section{Multidisciplinarietà}

Le singole discipline costituiscono degli ambienti di lavoro 'interni', dove si addensano competenze specialistiche e operano comunità specializzate, ma allo stesso tempo esse si devono interfacciare con ambienti esterni, entrando in relazione tra loro secondo diverse dinamiche, che possono andare dalla competizione e dalla critica, allo stimolo costruttivo e allo scambio di idee, metodi e concetti. Dal punto di vista della competizione tra i vari ambiti si può osservare che, sebbene in origine i confini tra discipline fossero considerati invariabili, oggi invece siano variabili nel tempo in funzione della spinta delle comunità scientifiche disciplinari che vanno esplorando domini confinanti o emergenti [Stichweh 200 I]. Per quanto concerne invece i rapporti di collaborazione tra discipline, si delinea il concetto generale di multidisciplinarietà, che si può declinare in interdisciplinarietà, pluridisciplinarietà 
Fig. 6. Giorgione (14981499 ○ $1502-1503$ ca. Museo Casa Giorgione, Castelfranco Veneto, rappresentazione delle rappresentazione delle meccaniche.

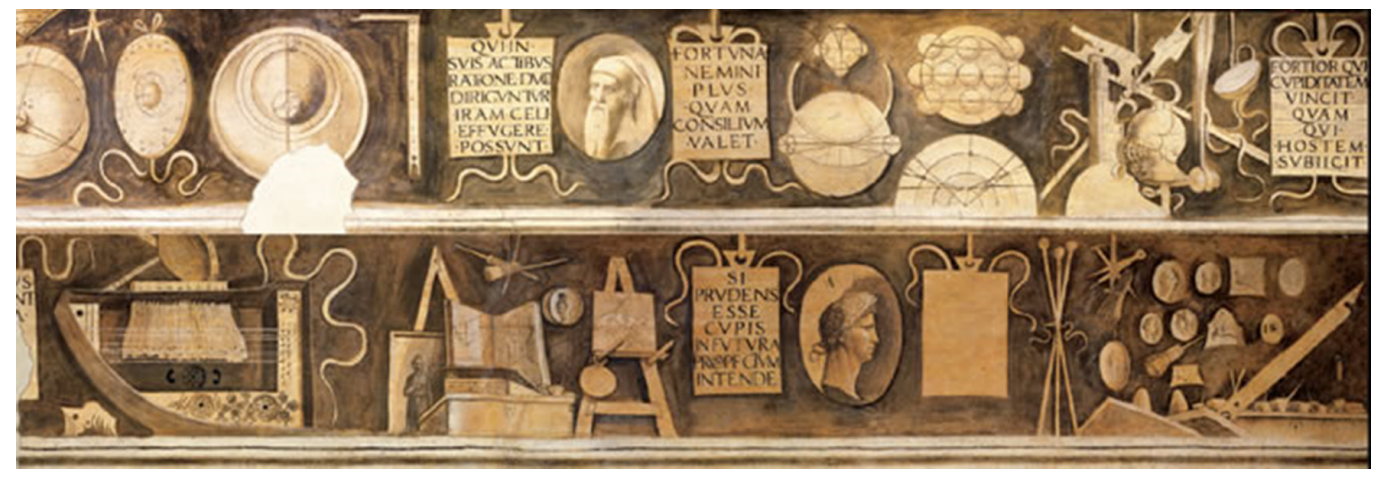

e transdisciplinarietà [Morval 1993], a seconda delle relazioni tra discipline, e in particolare: - pluridisciplinarità: implica giustapposizione di varie discipline in un particolare ambito, senza alcuna interazione sul piano metodologico. Le discipline condividono il soggetto studiato, ma mantengono la propria episteme;

- interdisciplinarità: implica l'interazione tra più discipline nello studio di un particolare soggetto. II grado di coinvolgimento può essere variabile, dal semplice confronto e scambio sino alla definizione di apparati concettuali condivisi in un'ottica di mutuo arricchimento [Piaget 1974];

- transdisciplinarità: implica la definizione epistemologica completamente nuova rispetto alle epistemologie delle singole discipline chiamate alla collaborazione. Essa necessita di coordinazione tra discipline e fa emergere da queste un oggetto nuovo, diverso dalle discipline originarie e allo stesso tempo ad esse riconducibili.

Inoltre, se in principio il numero delle discipline era limitato e definito, e tra loro poteva essere evidenziata una rigida gerarchia [Hoskin 1993, p. 274], oggi tali limiti e rapporti perdono il loro significato in quanto nuove discipline si vanno continuamente affermando, altre spariscono o si disattivano temporaneamente all'interno di un sistema di partizione della conoscenza privo di centri e di gerarchie [Stichweh 200I].

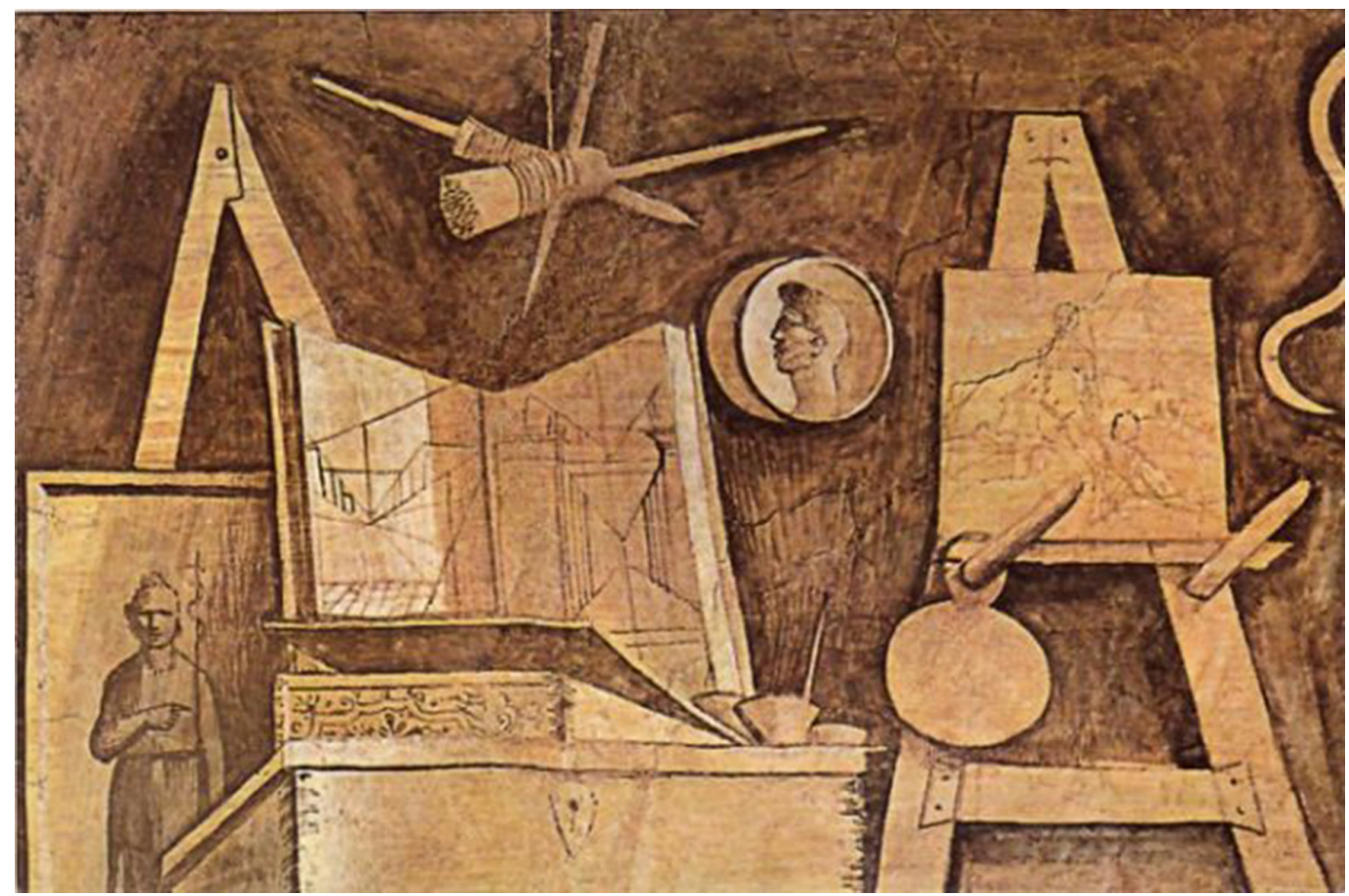

Fig. 7. Giorgione (14981499 o | 502-I503 ca). Museo Casa Giorgione, Castelfranco Veneto arti liberali e delle arti meccaniche. 
Fig. 8. Samuel Taylor Coleridge (1818), Encyclopaedia Metropolitana; Or, Preliminary Treatise on Method, p. 44

Fig. 9. Rappresentazione del sistema della conoscenza umana dell'Encyclopédie ( 175 e 1772).
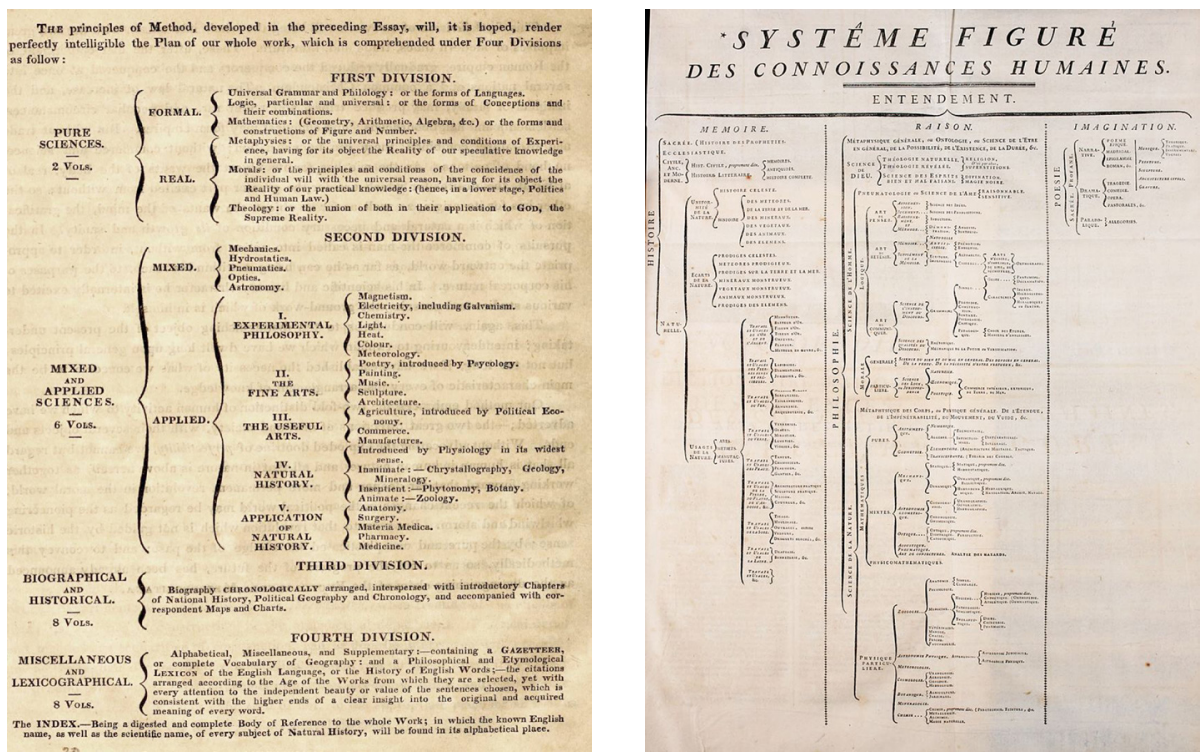

A sostegno dell'interdisciplinarietà, Nissani ricorda che ogni processo creativo necessita una conoscenza e un approccio interdisciplinare in quanto la creazione di qualcosa di nuovo implica la combinazione inedita di idee precedentemente distanti [Koestler 1964; Simonton 1988]. La creazione di nuove idee può anche nascere dalla loro permutazione tra diverse discipline, dallo scontro e dall'incontro tra differenti culture [Snow 20 I2] capace di ampliare il pensiero slegandolo dalle posizioni tradizionali consolidate verso nuovi orizzonti e visioni [Milgram 20 I 7].

Abbott distingue tra ricerca theory-driven e ricerca problem-driven [Abbot 20 I 5] evidenziando come la prima necessiti di conoscenza disciplinare, mentre la seconda richieda necessariamente delle competenze interdisciplinari. Infatti, i problemi emergenti della società tendono ad essere maggiormente di tipo interdisciplinare. Alcuni dei temi di ricerca emergenti, proprio per il loro essere inediti e provenienti dalla società, spesso si collocano al confine tra le discipline tradizionali. La problematicità di questi temi ha origine proprio dalla difficoltà di collocamento degli stessi nei campi del sapere consolidati, che finiscono così con l'occupare interstizi più difficilmente riconoscibili e indagabili [Huber 1992 p. 285; Campbell 1969; Kavaloski 1979; Kockelmans 1979]. Queste aree grigie e interstiziali sono gli ambiti di ricerca in cui diventa necessario un approccio interdisciplinare che per questo richiede maggiori sforzi ed energie, in quanto implica il confronto con molteplici conoscenze, tradizioni disciplinari, linguaggi e sensibilità [Nissani 1997].

\section{Disciplinarietà, interdisciplinarietà e transdisciplinarietà nelle Scienze Grafiche}

a) Disciplinarietà e globalizzazione del sapere disciplinare

Differentemente dal panorama del diciannovesimo secolo, in cui le comunità scientifiche erano strettamente nazionali [Crawford et al. 1993; Stichweh 1996], il sistema delle discipline scientifiche è oggi globale. Per questo motivo diventa urgente delineare i confini disciplinari dei saperi legati a rappresentazione, espressione, comunicazione e visualizzazione grafica, in relazione non solo alle singole tradizioni e ai singoli contesti nazionali, ma rispetto al più ampio e complesso panorama internazionale. Nel caso delle discipline del disegno emerge la necessità, ma anche l'opportunità, di riferirsi alle più generali scienze grafiche [Cardone 2016] che per la loro poliedricità e molteplicità devono essere viste non come una disciplina unitaria con metodi e obiettivi monolitici univocamente e preventivamente determinati, ma piuttosto come un insieme di campi di studio dotato di un repertorio di interessi non unitario [Eco 2016] ma articolato secondo una geografia e una genealogia complesse, molteplici, non gerarchiche e dinamiche [Cicalò 2020]. 


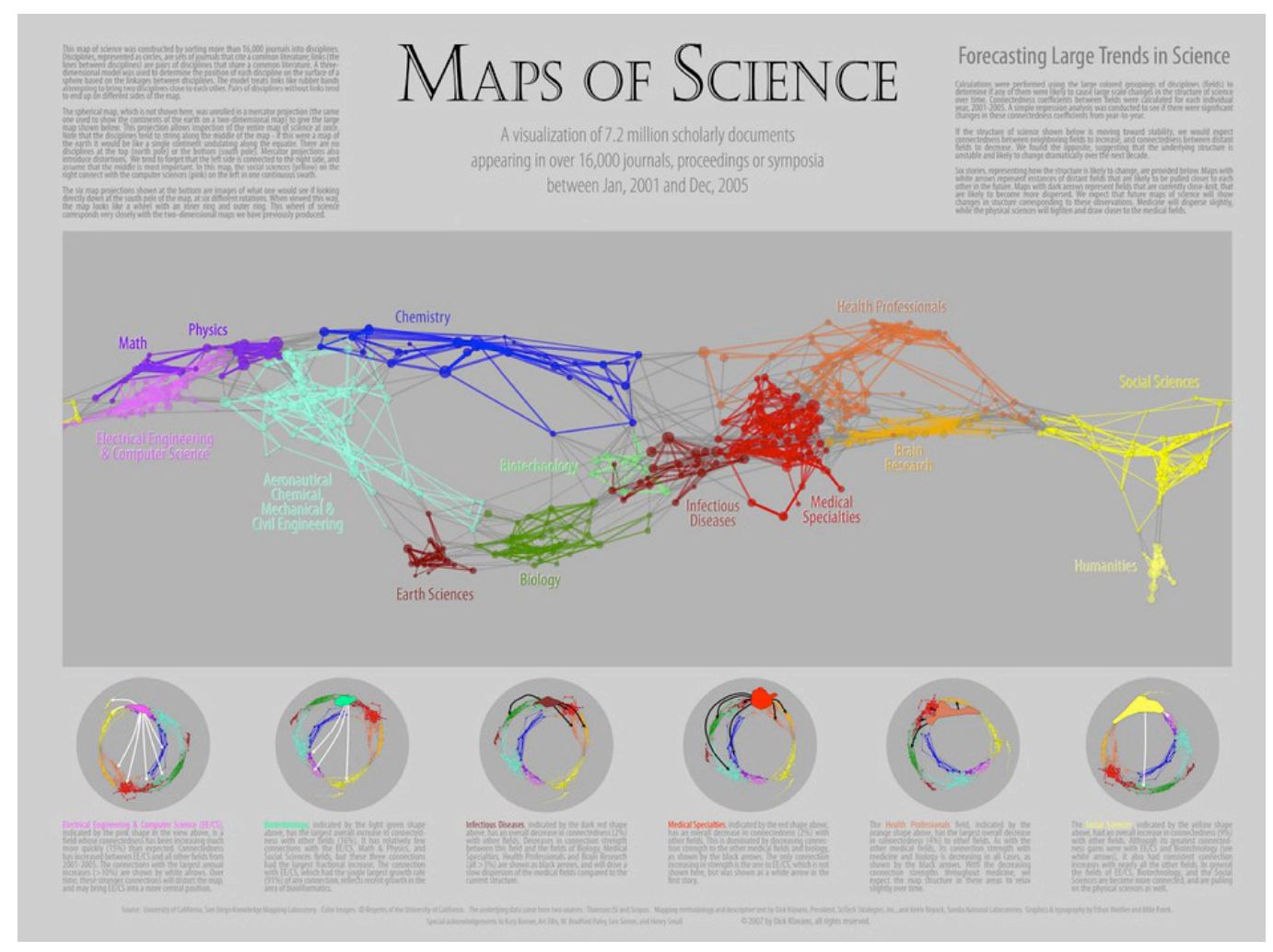

Figg. 10, 1 1. Klavans, Richard and Kevin W. Boyack. 2007. Maps of Science: Forecasting Large Trends in Science. Courtesy of Richard Klavans, SciTech

Strategies Inc. In "3rd

Strateges, Inc. In "3rd

Powion (2007): The

Places \& Spaces: Mapping

Science, edited by Katy

Börner and Julie M. Davis:

<http://scimaps.org>.

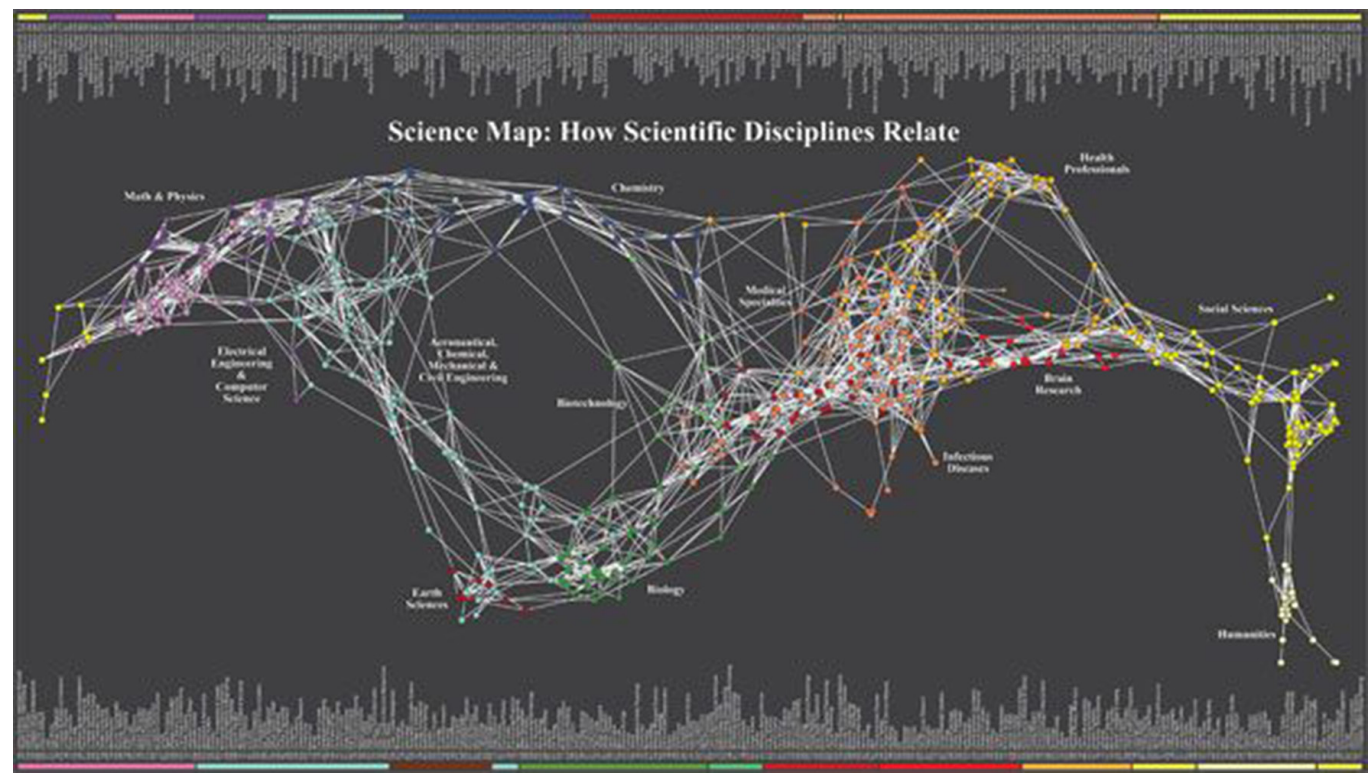


Fig. 12. Mappa delle connessioni tra saperi basata sui link tra riviste scientifiche [Bollen, Van de Sompel, Hagberg et al. 2009]: <https://doi. org/ $10.137 \mid /$ journal. pone.0004803>.

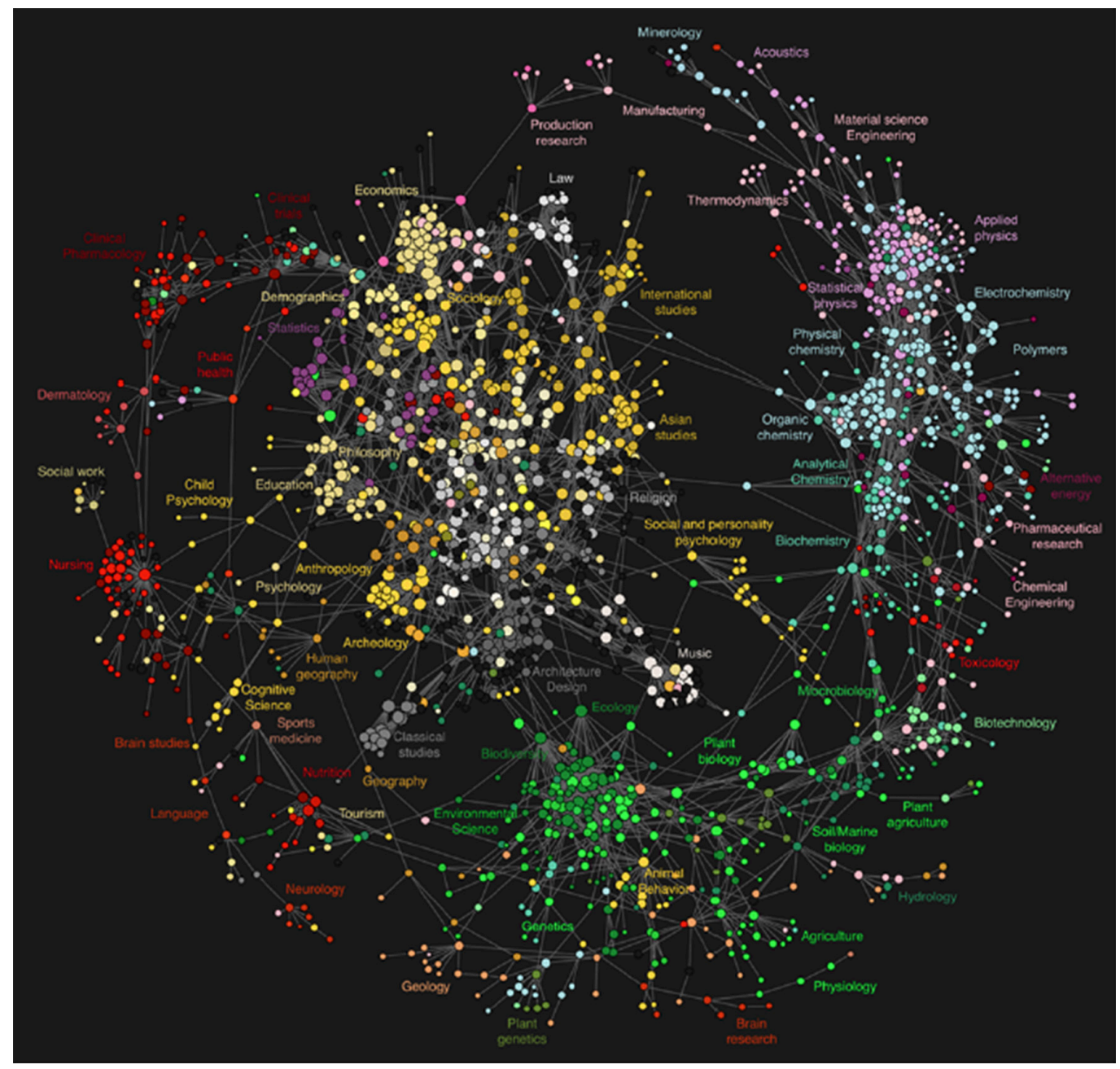

b) Interdisciplinarietà e diaspora del sapere disciplinare

Molte discipline hanno incorporato nel corso del tempo componenti significative delle Scienze Grafiche all'interno dei propri corpus disciplinari. Questa tendenza ha subito una rapida accelerazione con la diffusione dei software per la rappresentazione, che ha favorito un processo di sostituzione delle competenze scientifico-disciplinari con i relativi strumenti tecnico-operativi. Questo fenomeno è osservabile in diversi campi del sapere tra cui le discipline che analizzano e studiano l'ambiente come le discipline naturali, le discipline progettuali e le discipline storico-archeologiche che hanno fatto propri i metodi, gli strumenti e le tecniche di rappresentazione grafica mettendoli al centro delle proprie attività didattiche e di ricerca, dando continuità a quella che può essere definita la diaspora dei paradigmi disciplinari delle discipline grafiche all'interno di altri ambiti disciplinari.

In tutte le forme di classificazione viste nel breve excursus storico presentato nei paragrafi precedenti, le discipline non vengono infatti mai esplicitate ma ricadono sempre all'interno delle scienze e delle arti per le quali tali conoscenze sono fondamentali. Come tutti i linguaggi, anche quello grafico costituisce infatti una competenza di base necessaria alla costruzione e alla comunicazione della conoscenza e diventa dunque una componente basilare connaturata allo stesso metodo scientifico. La ricerca e l'esplorazione dei diversi soggetti osservabili o anche semplicemente intuibili, spesso non può infatti prescindere dalla loro rappresentazione grafica. Le attività di ricerca delle varie discipline che studiano soggetti e fenomeni visibili e invisibili finisce così con il coincidere con la loro rappresentazione senza la quale diventa impossibile la comprensione degli stessi soggetti. Per le varie discipline si 
rende dunque necessario fare propri gli strumenti di rappresentazione grafica per poter sviluppare le ricerche, soprattutto quando è sufficiente farlo attraverso l'uso di strumenti e tecnologie digitali.

Sebbene questo non implichi un problema per le attività di ricerca strettamente disciplinari, può invece costituire un ostacolo per quella interdisciplinare in cui la riconoscibilità e l'autonomia delle singole discipline è una condizione necessaria senza la quale non può esserci interdisciplinarietà.

c) Transdisciplinarietà e ricerca dell'identità disciplinare

Parlare oggi di Scienze Grafiche obbliga ad adottare un approccio di tipo transdisciplinare per almeno due motivi: uno legato ai caratteri intrinseci e alla storia della disciplina, l'altro alle sue relazioni attuali con le altre discipline e alla sua riconoscibilità in ambito internazionale. La prima sollecitazione ad adottare uno sguardo transdisciplinare è legata alla necessità di ricostruire i confini di un ambito di ricerca, di ridefinire quello sguardo peculiare con cui osservare e conoscere il mondo, raccogliendo i frammenti dispersi dopo la diaspora disciplinare precedentemente ipotizzata, che ha diffuso allinterno di altri campi disciplinari metodi, strumenti, tecniche e competenze, per ricostruire un corpus disciplinare peculiare e riconoscibile. La seconda sollecitazione è invece legata alla necessità di dare una collocazione alle discipline grafiche nel panorama scientifico internazionale. Basti pensare, ad esempio, alle difficoltà di riconoscimento di queste competenze nel quadro dei settori ERC -European Research Council - e alla necessità di descrivere questo ambito di indagine attraverso una somma delle sue possibili componenti rintracciabili all'interno dei differenti settori ERC. Pur riconoscendo i limiti della classificazione ERC e delle procedure con cui esse vengono definite in relazione ai progetti di ricerca precedentemente finanziati all'interno della stessa istituzione, tale difficoltà di collocamento delle scienze grafiche nell'ambito della classificazione dei saperi condivisa a livello internazionale richiama a ripensare l'identità disciplinare con l'obiettivo di rendersi maggiormente riconoscibili, visibili e capaci di rispondere alla domanda di ricerca interdisciplinare proveniente dalla società.

\section{Riferimenti bibliografici}

Abbott Andrew (200 I). Chaos of Disciplines. Chicago: University Chicago Press.

Aldrich John H. et al. (eds). (20 I4). Interdisciplinarity: its role in a discipline-based academy. A report by the Task Force of the American Political Science Association. New York: Oxford University Press.

Campbell Donald T. (1969). Ethnocentrism of Disciplines and the Fish-Scale Model of Omniscience. In Sherif Muzafer, Wood Sherif Carolyn (eds.). Interdisciplinary Relations in the Social Sciences. Chicago: Aldine.

Cardone Vito (2016). Immaginare un'area culturale delle immagini visive. In XY, I (I), 20 I6, pp. I2-27.

Cicalò Enrico (2019). Graphic, Visual and Image Sciences. In Luigini Alessandro, Panciroli Chiara (eds.). Img journal 0I/20I9 Manifesto, pp. 106-II5.

Cicalò Enrico (2020). Exploring graphic sciences. In Cicalò Enrico (eds.). Proceedings of the II International Conference on image and imagination. Berlin/Heidelberg: Springer.

Crawford Elisabeth T., Elisabeth Crawford, Terry Shinn et al. (eds.). (1993). Denationalizing science: the contexts of international scientific practice. Berlin/Heidelberg: Springer.

Cummings Richard J. (1989). The interdisciplinary challenge: Connection and balance. In National Forum, 69. (2), 1989, pp. 2-4.

Gardner Howard (2015). Cinque chiavi per il futuro. Milano: Feltrinelli.

Gass J. R. (1972). Preface. In Centre for Educational Research and Innovation (eds.). Interdisciplinarity, pp. 9- I0. Nice: OECD.

Goodlad Sinclair (1979). What Is an Academic Discipline? In Roy Cox (ed.). Cooperation and Choice in Higher Education. London: University of London Teaching Methods Unit.

Eco Umberto (2016).Trattato di semiotica generale. Milano: La nave di Teseo.

Gusdorf G. (1979). Why interdisciplinarity? In Kockelmans Joseph J. (ed.). Interdisciplinarity and Higher Education. University Park: Pennsylvania State University Press, pp. I23-160.

Huber Ludwig, Shaw Gisela (1992). Towards a New Studium Generale: Some Conclusions. In European fournal of Education, 27, pp. 285-301. 
Kavaloski Vincent C. (1979). Interdisciplinary Education and Humanistic Aspiration: A Critical Reflection. In Kockelmans Joseph J. (ed.). Interdisciplinarity and Higher Education. University Park: Pennsylvania State University Press, pp. I23-160.

Klein Thompson Julie (1990). Interdisciplinarity/History, Theory, and Practice. Detroit:Wayne State University Press.

Kockelmans Joseph J. ( 1979). Why Interdisciplinarity? In Kockelmans Joseph J. (ed.). Interdisciplinarity and Higher Education. University Park: Pennsylvania State University Press, pp. 123-160.

Kuhn Thomas S. (2012). The Structure of Scientific Revolutions. Chicago:University of Chicago Press.

Massironi Manfredo (2002). The psychology of graphic images: Seeing, drawing, communicating. Mahwah, New Jersey: Lawrence Erlbaum Associates.

Miles Leland (1989). Renaissance and Academe. In National Forum, 69: I5- 17.

Milgram Stanley (2017). Interdisciplinary thinking and the small world problem. In Muzafer Sherif and Caroline W. Sherif (eds.), Interdisciplinary Relations in the Social Sciences. Chicago: Aldine, pp. 103-120.

Mitchell William J.T. (20 I8). Scienza delle immagini. Iconologia, cultura visuale ed estetica dei media. Milano: Johan \& Levi.

Morval Monique (1993). La recherche interdisciplinaire: une difficile intégration. In de Gaulejac Vincent, Roy Shirley (eds.). Sociologies cliniques. Paris: Hommes et perspectives.

Nissani Moti (1997). Ten cheers for interdisciplinarity: The case for interdisciplinary knowledge and research. In The social scomandoience journal, 34(2), pp. 201-216.

Piaget Jean (1974). L'épistémologie des relations interdisciplinaires. In Schwarz Richard (ed.). Internationales Jahrbuch für interdisziplinäre Forschung. Vol I. Wissenschaft als interdisziplinäres Problem. Berlin-New York: De Gruyter, pp. I 54- 17 I.

Snow Charles P. (2012). The Two Cultures. London: Cambridge University Press.

Stichweh Rudolf (200 I). History of Scientific Disciplines. In N.J. Smelser, P.B. Baltes (eds). International Encyclopedia of the Social \& Behavioral Sciences, 20, pp. 3727-31. Amsterdam: Pergamon.

Suzuki Kenjiro (2002). Activities of the Japan society for graphic science - research and education. In J. Geometry Graphics, 6(2), 2002, pp. $221-229$.

\section{Autore}

Enrico Cicalò, Università degli Studi di Sassari, encic@uniss.it

Per citare questo capitolo: Cicalò Enrico (2020). Connessioni tra saperi: disciplinarietà, interdisciplinarietà e transdisciplinarietà delle scienze grafiche/Connections between knowledge: disciplinarity, interdisciplinarity and transdisciplinarity of graphic sciences. In Arena A., Arena M., Brandolino R.G., Colistra D., Ginex G., Mediati D., Nucifora S., Raffa P. (a cura di). Connettere. Un disegno per annodare e tessere. Atti del $42^{\circ}$ Convegno Internazionale dei Docenti delle Discipline della Rappresentazione/Connecting. Drawing for weaving relationships. Proceedings of the 42 th International Conference of Representation Disciplines Teachers. Milano: FrancoAngeli, pp. 316-337. 


\title{
Connections between Knowledge. Disciplinarity, Interdisciplinarity and Transdisciplinarity of Graphic Sciences
}

\author{
Enrico Cicalò
}

Abstract

This article discusses the evolution of disciplines focused on graphic representation in relation to the process of fragmentation of knowledge in increasingly specialized scientific fields. This discussion is based on an analysis of the literature on the history of science, arts and academic disciplines, which confirms the fundamental role of graphic skills in the development of thought and in the exploration of different fields of knowledge. This is precisely what leads graphic science to be subject to a sort of diaspora within the most diverse disciplinary fields, that tend to incorporate the technical methods and tools of the Graphic Sciences into their own disciplinary corpus. From the discussion of the relationships and connections that have developed over time among the disciplines, it is possible to highlight the need to give identity and visibility to the Graphic Sciences, which today are difficult to place within the international classifications of the scientific research domains, through a transdisciplinary path aimed at redesigning the identity of the Graphic Sciences both internally, through the definition of the fields of investigation, and externally, through the definition of possible and fertile connections with other knowledge in order to be able to give answers to interdisciplinary research questions coming from society, and thus redefining their role within the geography and genealogy of scientific knowledge.

Keywords

integration of knowledge, fields of knowledge, academic disciplines, graphic sciences, history of science.

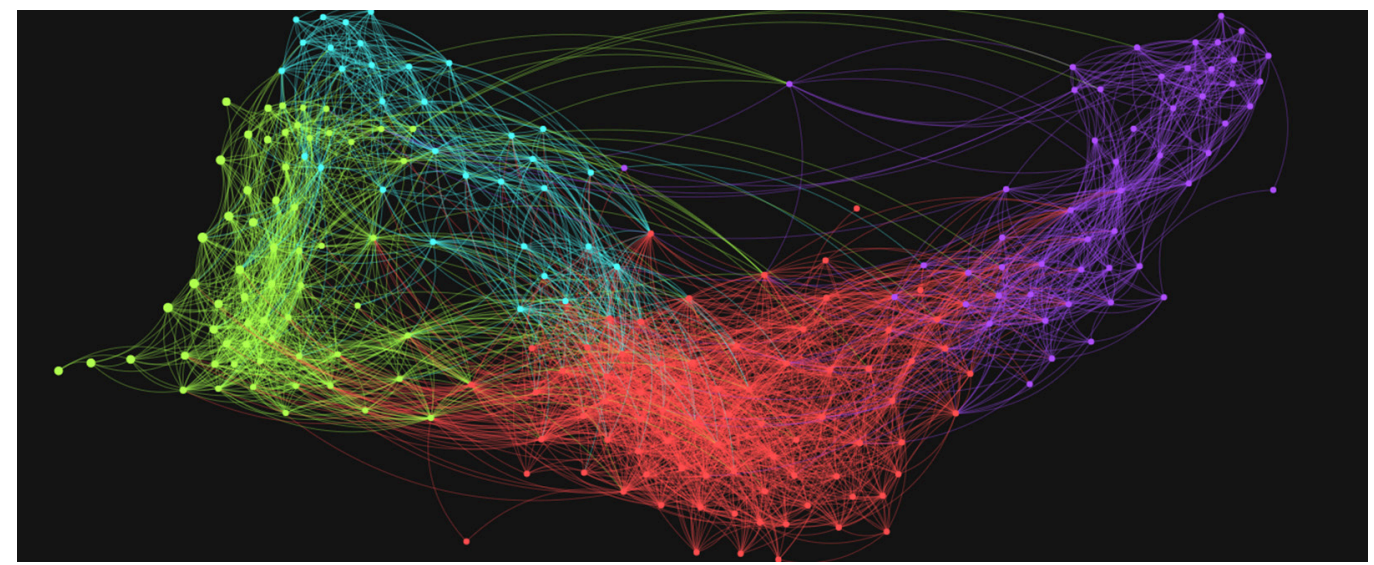


Fig. 1. Herrad von Landsberg, Hortus deliciarum, I I 80. Representation
of the liberal arts.

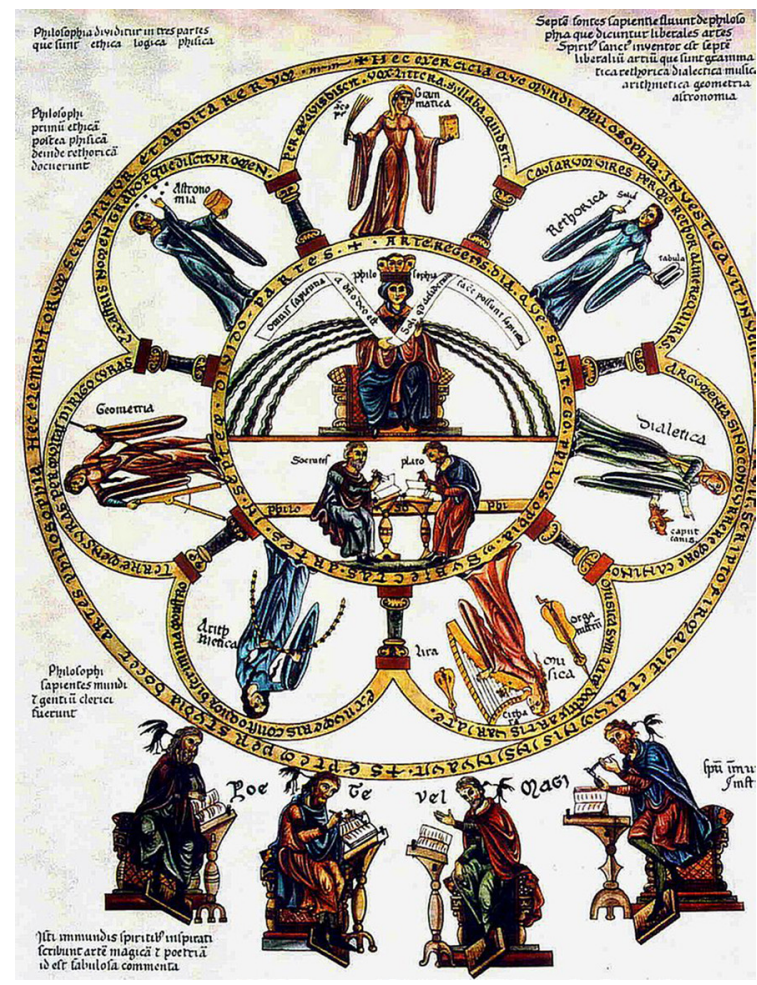

\section{Pre-disciplinarity}

In the classical era, science had a pre-disciplinary nature. Plato, in The Republic, describes intelligible knowledge as a unitary sphere, distinguishable only from sensitive knowledge, which can be investigated through an exploratory approach of philosophical nature capable of analyzing the entire sphere of knowledge. It is Aristotle, in book VI of Metaphysics, to hypothesize a first subdivision of knowledge into fields of investigation - theoretical sciences, practical sciences and poietic or productive sciences - inaugurating what will be the tendency to subdivide the sciences into units of specialized knowledge [Klein Thompson 1990, p. 19] that will characterize the history of science to the present day. In Roman times there will remain the tendency to fragment the different fields of knowledge through the formulation of the distinction between liberal arts (trivium articulated in grammar, rhetoric and dialectics; and quatrivium articulated in arithmetic, geometry, astronomy and music) to which the mechanical arts, formalized only in medieval times, are opposed - lanificium, armatura (all work in wood, stone, metal, weaponry, architecture, sculpture, painting), navigatio (including commerce), agricultura, venatio, medicina, theatrica.

These were given less consideration as they were considered to be exclusively manual and not intellectual skills. It was in the Renaissance that the two skills were to join together in those intellectual artists able to rediscover a concept of knowledge as a unitary sphere. With the invention of the press, the intensification of contacts between different regions and the economic development, the production and diffusion of knowledge accelerated, stimulating the need to archive and classify knowledge, paving the way for disciplines, as systems of production and archiving of knowledge [Stichweh 200 I].

It is the diffusion of scientific publishing products that encourages the specialization of skills and the consequent formation of communities of specialists, which will be indispensable for the functioning of the various disciplines [Kuhn 20 I2]. In particular, after 1780, specialized scientific journals began to circulate in France, Germany and England, becoming not only a channel for the diffusion of disciplinary knowledge but real tools for the construction of the disciplines themselves, through the construction of communities of specialists interested in 
the particular topics explored in the journal. Therefore, the community chooses a particular scientific publication and at the same time further develops its specialization through it [Stichweh 200 I].

If science, according to the pre-disciplinary classical philosophical tradition, was aimed at the seeking of the truth, in the disciplinary phase it is oriented to the search for innovation in accordance with the same scientific publicity [Stichweh 200 I]. This production of immense quantities of new knowledge makes impossible for a single scholar to deal with the whole sphere of knowledge, requiring instead the formation of isolated areas of knowledge [Cummings 1989]. The figure of a scholar capable of dealing transversally with different spheres of knowledge, as was the case in early classical antiquity and the Renaissance, therefore no

Fig. 2. Andrea Pisano and collaborators (1334- | 360), Campanile di Giotto, Santa Maria del Fiore, Florence. Representation of trades and humanities.

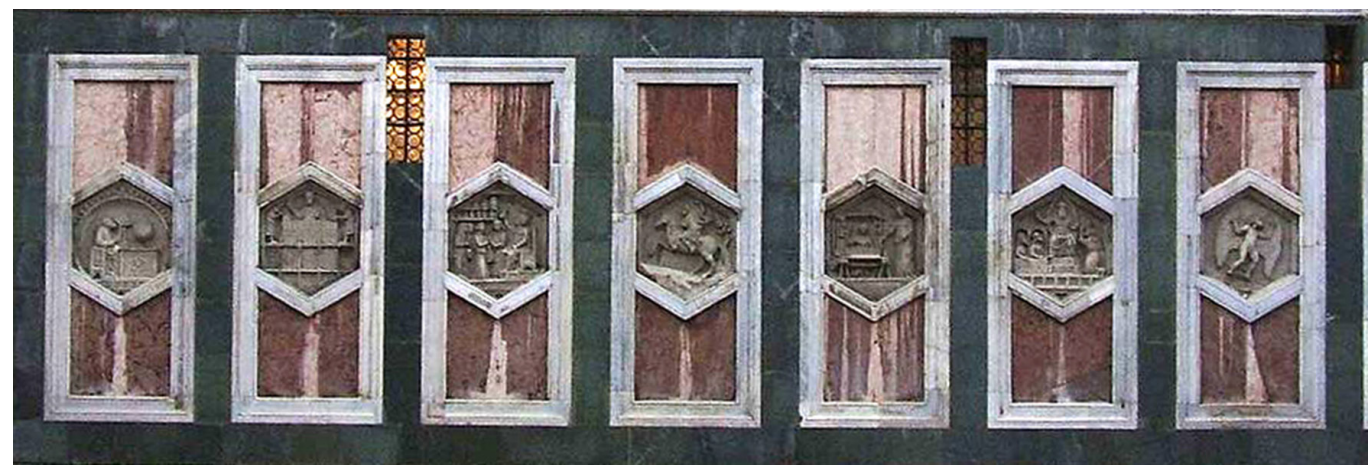

longer seems conceivable. In the last centuries the passage from an idea of unity of knowledge to an idea of specialization of knowledge has thus definitively ended [Nissani 1997]. In Western culture, in particular, has gradually accentuated the division between what Snow [Snow 20I2] defines as "the two cultures of knowledge", the humanistic and the scientific, each containing a multitude of cultures, each of which delimits its own territory and often refuses to dialogue with the others, causing important consequences in the development of scientific thought.

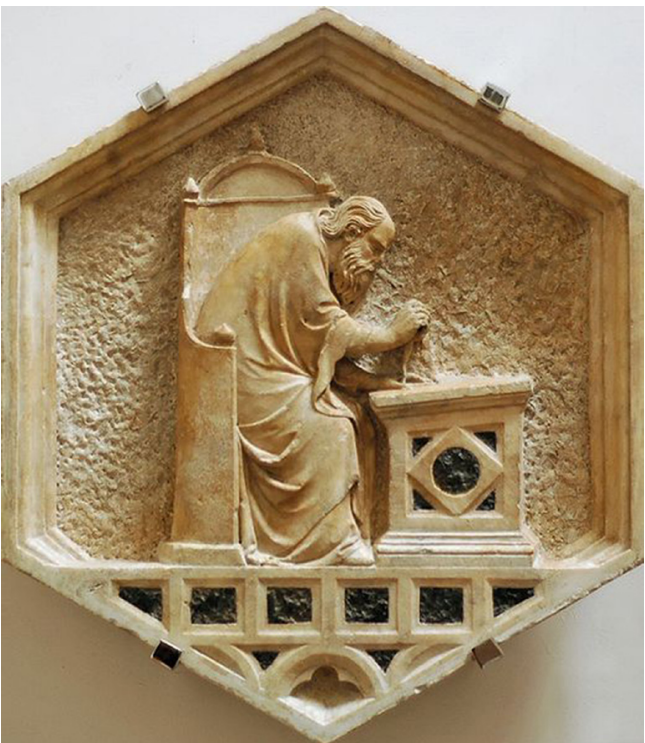




\section{Disciplinarity}

As introduced in the previous paragraph, a discipline can be defined as an autonomous and independent domain of human experience in which a community of experts is to be identified [Nissani 1997].The term discipline derives from the Latin discere and is therefore closely linked to the transmission of knowledge within the various educational paths. The discipline therefore represents a teaching domain, generally connected to the skills required by the world of work and professions [Stichweh $200 \mathrm{I}$ ].

According to Goodland [Goodland 1979], in order to define a field of knowledge as a discipline, it is necessary that some requirements are satisfied:

I) disciplines have a particular research subject, which can also be shared with other disciplines;

2) disciplines have a baggage of knowledge produced over time on that particular research subject, in this case not shared with other disciplines;

3) disciplines must have theories and concepts that can organise the specialist knowledge produced;

4) disciplines use specific terminologies and technical languages in relation to their research subjects;

5) disciplines have their own methods of investigation;

6) disciplines formalize themselves within institutions through teachings in educational pathways, within departments and associations.

Scientific disciplines not only have the task of dividing knowledge into components that are easier to govern and study, but also to enable institutions to organise themselves more efficiently in the fields of research and teaching [Gass 1979, p. I 19], in line with the trend in Western culture towards competition and the achievement of excellence [Gusdorf 1979, p. 147].

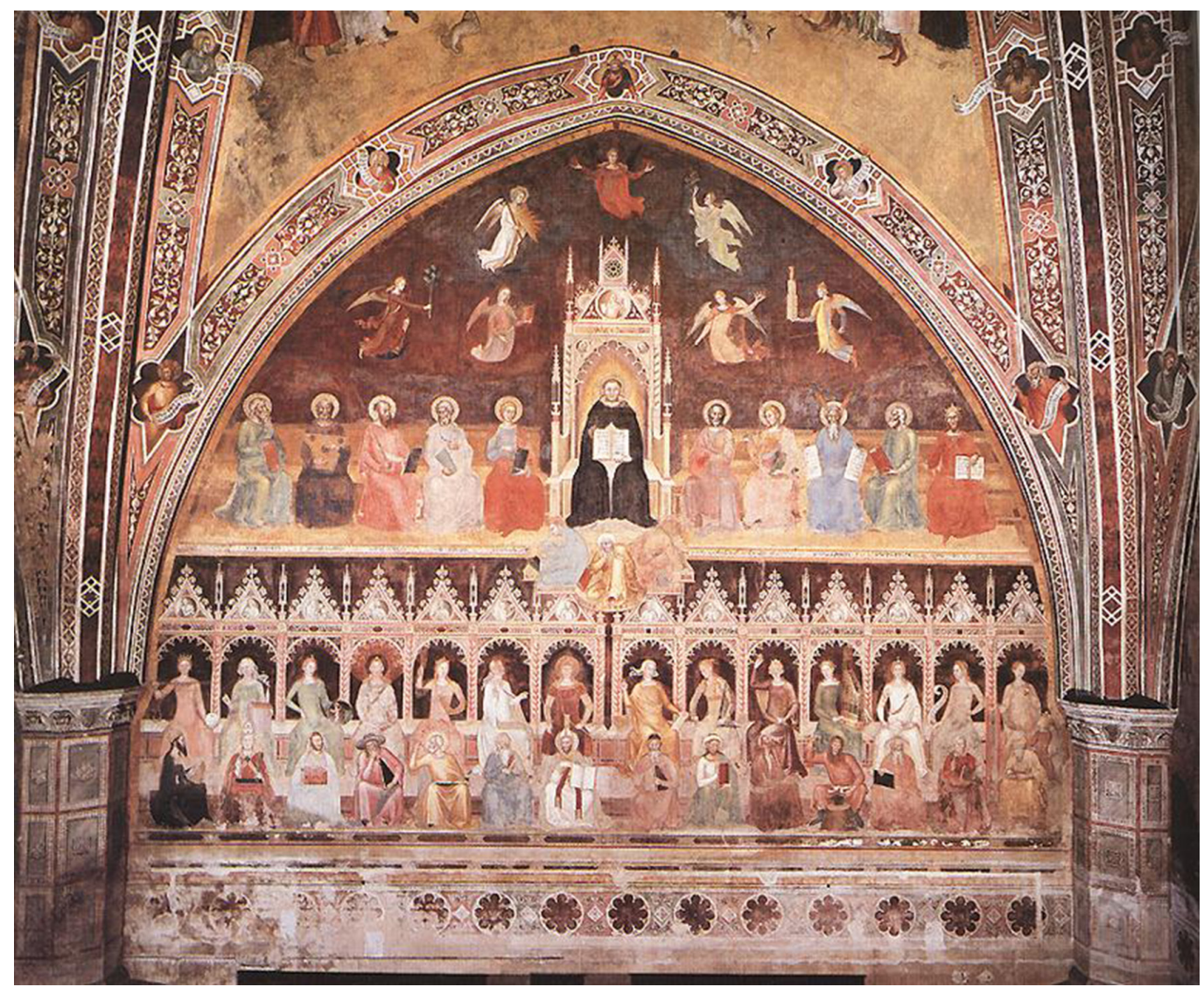




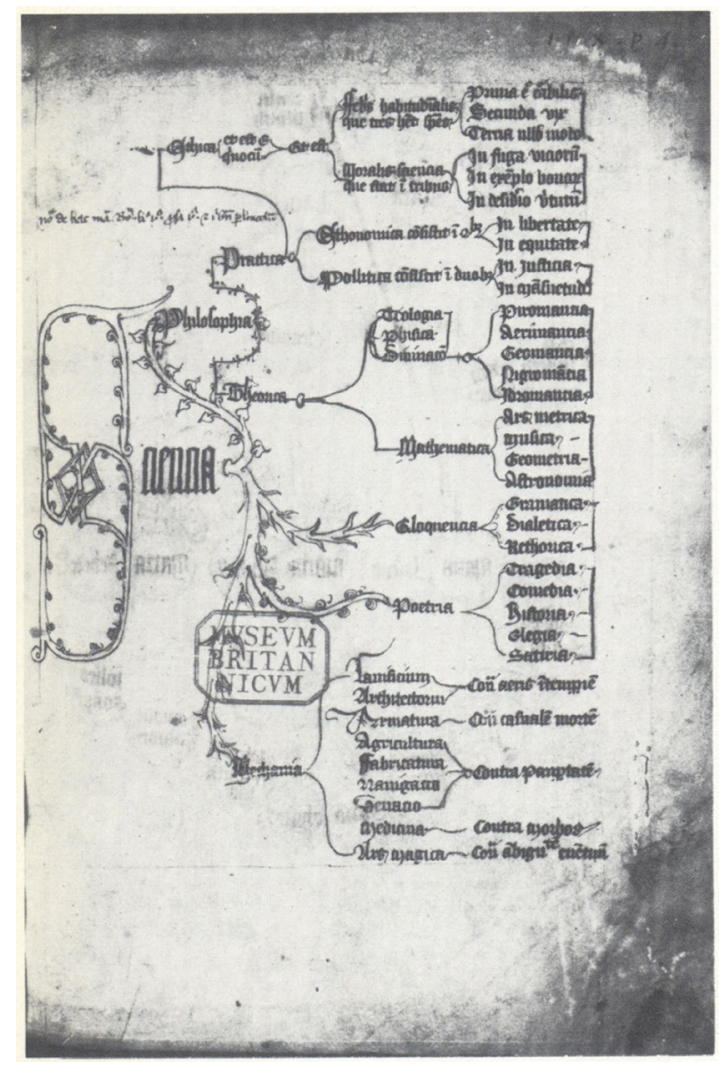

In addition to merely classifier, practical and organizational tasks, the disciplines also play a fundamental role in the psycho-cognitive field. Howard Gardner believes it is essential that people can be able in the future to think in the ways that characterize the major disciplines. He considers disciplinary thinking as one of the Five keys to the future most appreciated today and that it will be even more so afterwards. It is one of the competences that govern the sphere of cognitive processes as well as that of human initiative [Gardner 20 I5]. Disciplinary intelligence, writes Gardner, governs a form of thought and must be considered as the cognitive mode that characterizes a particular discipline, a certain job or a given profession. According to Gardner [Gardner 20 I5] a discipline represents a sphere of competence and at the same time a peculiar way of looking at the world. Without disciplines there can be no interdisciplinarity [Aldrich 2014]. Interdisciplinarity requires strong disciplines with equally strong methods, techniques, tools, historical traditions, theoretical and cultural apparatus.

\section{Multidisciplinarity}

The individual disciplines constitute "internal" working environments, where specialist skills are gathered and specialised communities operate, but at the same time they have to interface with external environments, entering into relationships with each other according to different dynamics, which can range from competition and criticism, to constructive stimulation and exchange of ideas, methods and concepts. From the point of view of competition between the various fields it can be observed that, although originally the boundaries between disciplines were considered invariable, nowadays they are instead variable in time according to the pressure of the disciplinary scientific communities that explore bordering or emerging domains [Stichweh 200 I].

With regard to the relationships of collaboration between disciplines, instead, the general 
Fig. 6. Giorgione (14981499 o I502-1503 ca.), Museo Casa Giorgione, Castelfranco Representation of liberal and mechanical arts.

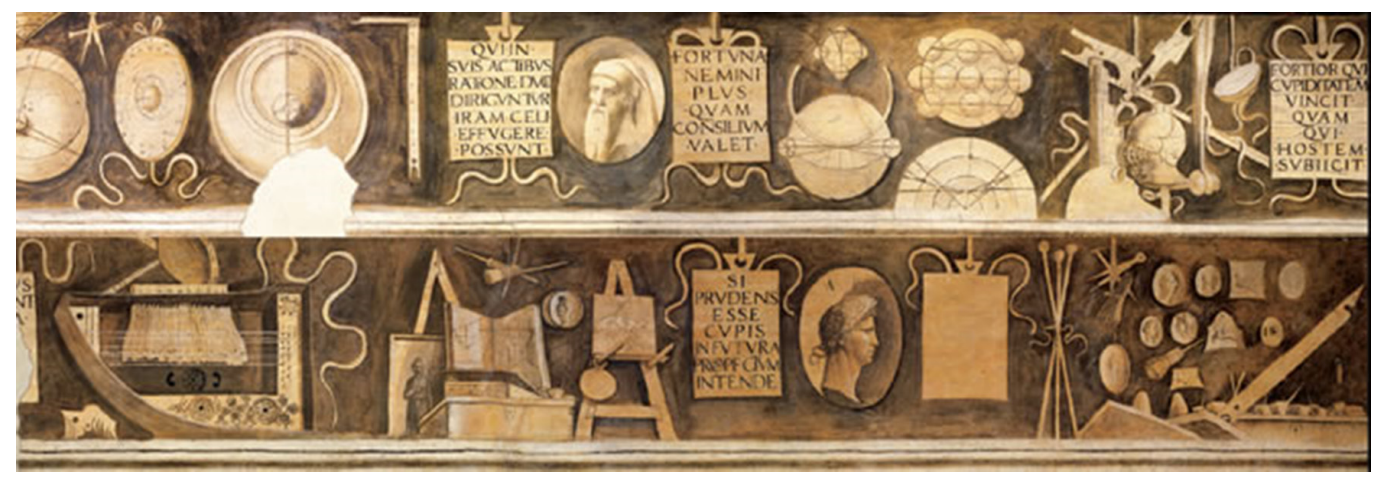

concept of multidisciplinarity emerges, which can be declined into interdisciplinarity, pluridisciplinarity and transdisciplinarity [Morval 1993], depending on the relationships between disciplines:

- Pluridisciplinarity: it implies juxtaposition of various disciplines in a particular field, without any methodological interaction. The disciplines share the subject studied, but maintain their own episteme;

- Interdisciplinarity: it implies the interaction between several disciplines in the study of a particular subject. The degree of involvement can be variable, from the simple comparison and exchange to the definition of shared conceptual apparatus in a perspective of mutual enrichment [Piaget 1974];

- transdisciplinarity: it implies a completely new epistemological definition with respect to the epistemologies of the individual disciplines called for collaboration. It requires coordination between disciplines and makes a new subject emerge from them, different from the original disciplines and at the same time referable to them.

Moreover, if in the beginning the number of disciplines was limited and defined, and between them a rigid hierarchy could be pointed out [Hoskin 1993, p. 274], today these limits

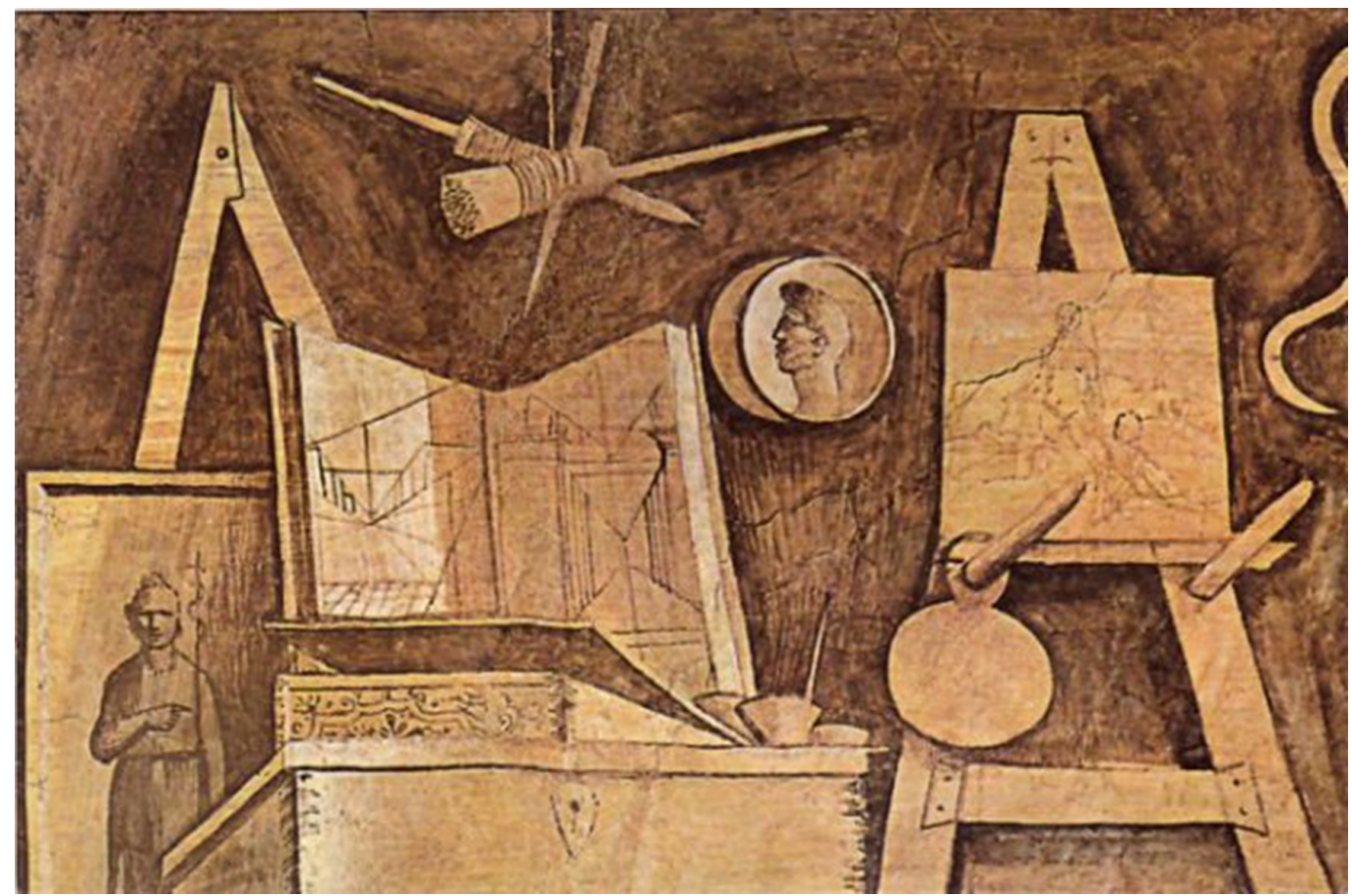


Fig. 8. Samuel Taylor Coleridge (18|8), Encyclopaedia Metropolitana; Or Preliminary Treatise on Method, p. 44

Fig. 9. Representation of the human knowledge system of the Encyclopédie (175I and 1772)
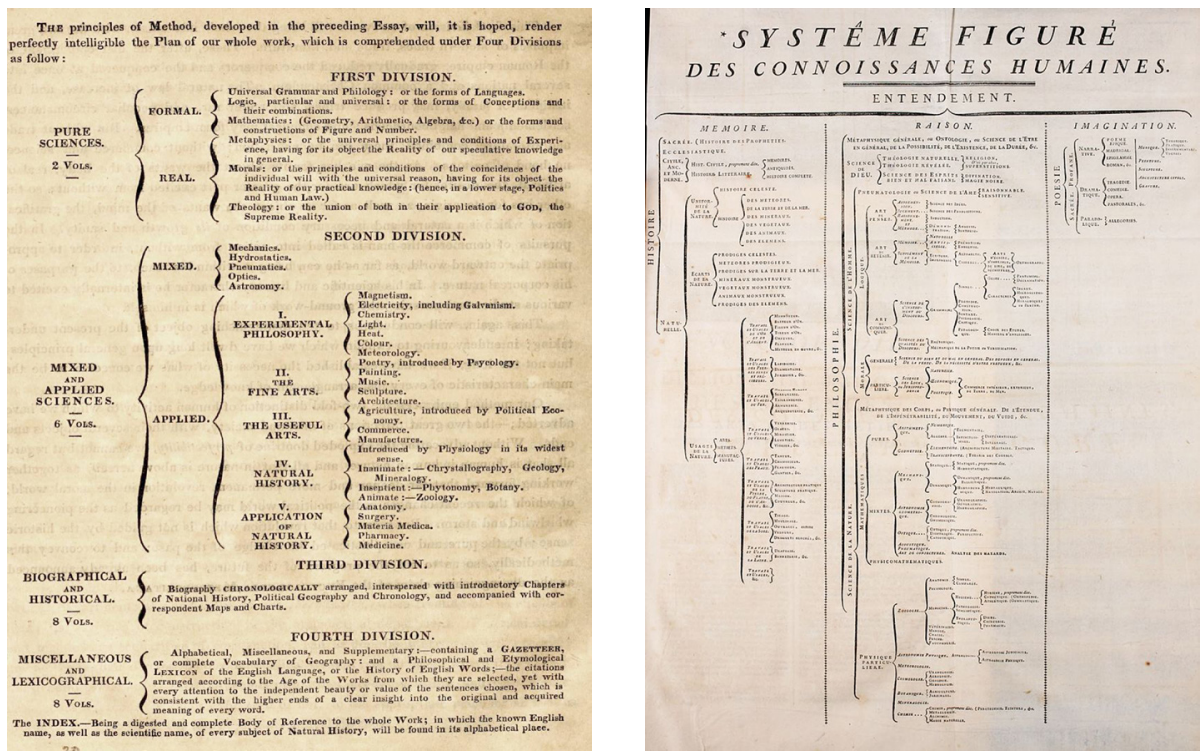

and relationships lose their meaning because new disciplines are constantly establishing themselves, others disappear or are temporarily deactivated within a system of knowledge partitioning without centres and hierarchies [Stichweh 200 I].

In support of interdisciplinarity, Nissani recalls that every creative process requires an interdisciplinary knowledge and approach because the creation of something new involves the unprecedented combination of previously distant ideas [Koestler 1964; Simonton 1988]. The creation of new ideas can also arise from their permutation between different disciplines, from the confrontation and the intersection of different cultures [Snow 20 I2] capable of expanding thought by untying it from established traditional positions towards new horizons and visions [Milgram 2017].

Abbott [Abbott 2015] distinguishes between theory-driven and problem-driven research, highlighting that the former requires disciplinary knowledge, while the latter necessarily requires interdisciplinary skills. In fact, emerging problems in society tend to be more interdisciplinary. Some of the emerging research themes, precisely because of their being new and coming from society, are often on the borderline between traditional disciplines. The problematic nature of these themes originates precisely from the difficulty of placing them in established fields of knowledge, which result in occupying interstices that are more difficult to recognize and investigate [Huber 1992, p. 285; Campbell 1969; Kavaloski 1979; Kockelmans 1979]. These grey and interstitial areas are the areas of research in which an interdisciplinary approach becomes necessary and for this reason requires greater effort and energy, as it implies the comparison with multiple knowledge, disciplinary traditions, languages and sensibilities [Nissani 1997].

\section{Disciplinarity, interdisciplinarity and transdisciplinarity in Graphic Sciences}

a) Disciplinarity and globalization of disciplinary knowledge

Differently from the scene of the nineteenth century, when scientific communities were strictly national [Crawford et al. 1993; Stichweh 1996], the system of scientific disciplines is now global. For this reason it becomes urgent to delineate the disciplinary boundaries of knowledge related to graphic representation, expression, communication and visualization, in relation not only to individual traditions and national contexts, but to the wider and more complex international panorama. In the case of the disciplines of drawing, there emerges the need, but also the opportunity, to refer to the more general Graphic Sciences [Cardone $2016]$ which, due to their versatility and multiplicity, must be seen not as a unitary discipline 
Figs. 10, 11. Klavans, Richard and Kevin W. Boyack. 2007. Maps of Science: Forecasting Large Trends in Science. Courtesy of Richard Klavans, SciTech Klavans, SciTech "3rd Strates (2007): The Iteration (2007): The Power of Forecasts," Places \& Spaces: Mapping Science, edited by Katy Börner and Julie M. Davis: <http://scimaps.org>.
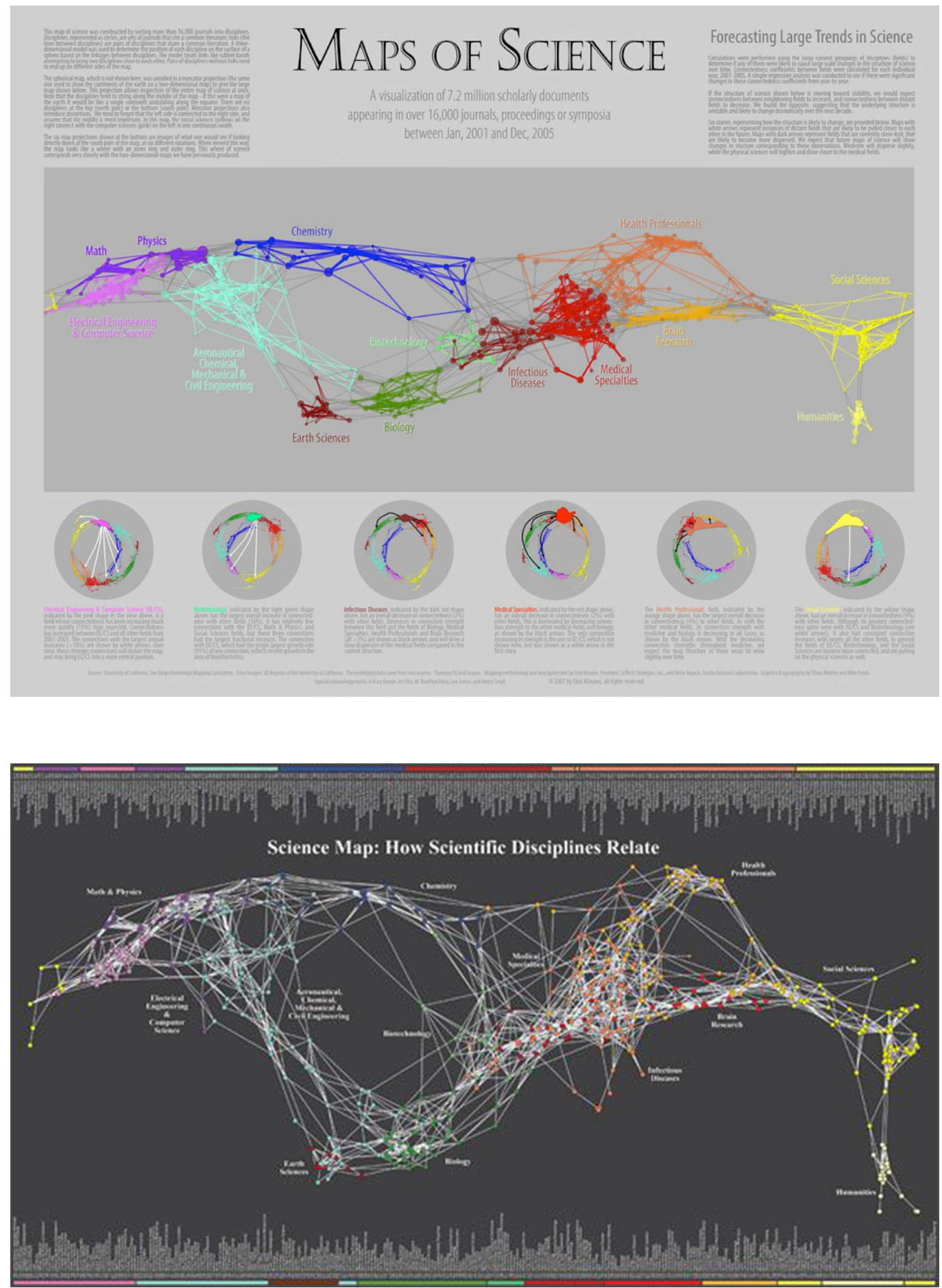
Fig. 12. Map of

connections based on link between scientific journa [Bollen, Van de Sompel Hagberg et al. 2009]: $<$ https://doi.org/10.1371/ journal.pone.0004803>.

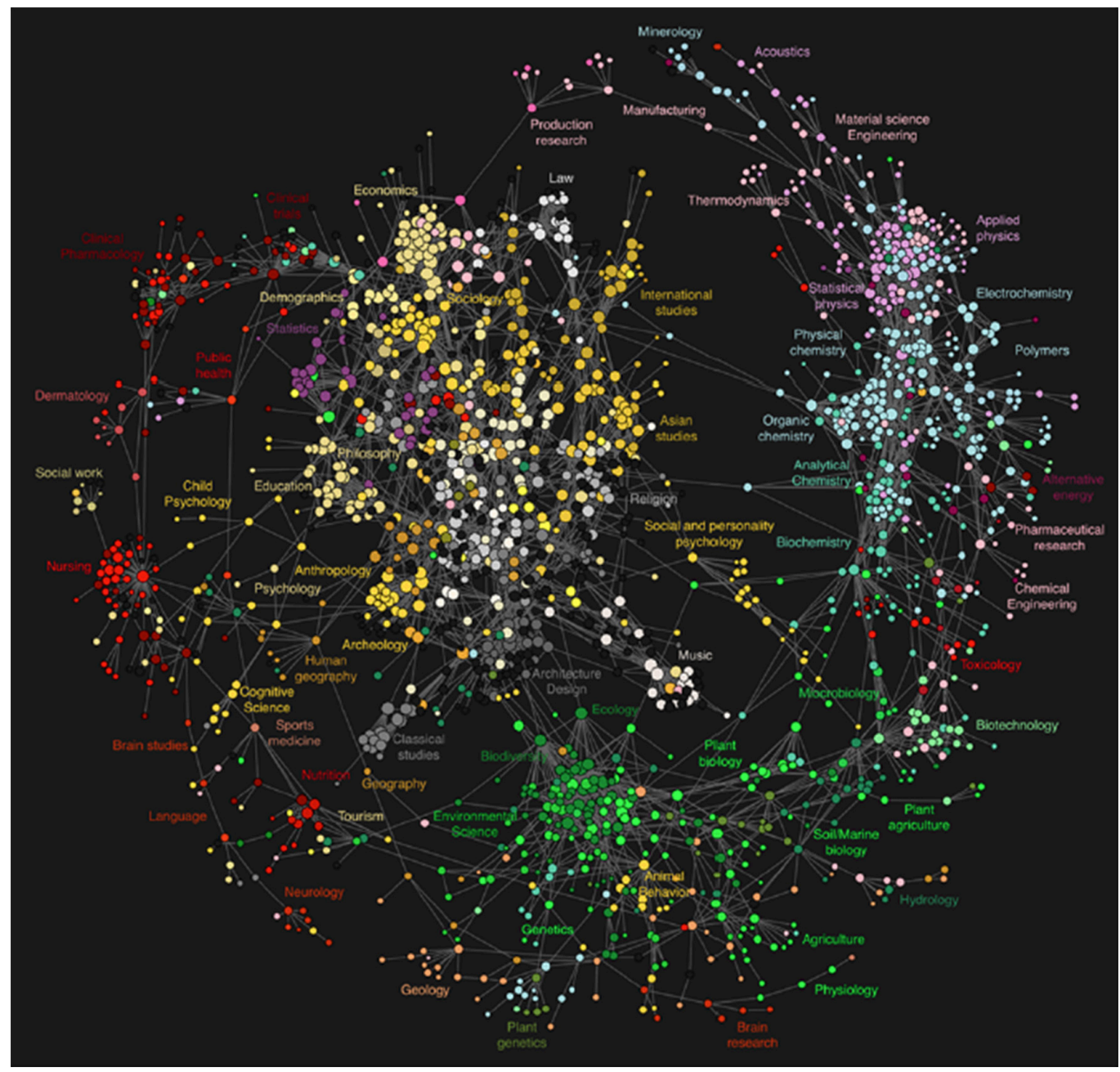

with univocally and previously determined monolithic methods and objectives, but rather as a set of fields of study endowed with a non-unitary repertoire of interests [Echo 2016 ] but articulated according to a complex, multiple, non-hierarchical and dynamic geography and genealogy [Cicalò 2020].

b) Interdisciplinarity and diaspora of disciplinary knowledge

Over the course of time, many disciplines have incorporated significant components of the Graphic Sciences into their disciplinary corpus. This trend has accelerated rapidly with the spread of digital representation software, which has fostered a process of substitution of scientific-disciplinary skills with the related technical-operational tools. This phenomenon can be observed in various fields of knowledge, including disciplines that analyze and study the environment, such as natural sciences, design disciplines and historical-archaeological disciplines that have adopted the methods, tools and techniques of graphic representation, putting them at the center of their teaching and research activities, giving continuity to what can be defined as the diaspora of disciplinary paradigms of graphic disciplines within other disciplinary fields.

In all the forms of classification seen in the brief historical excursus presented in the previous paragraphs, the graphic disciplines are in fact never made explicit but always fall within the sciences and arts for which such knowledge is fundamental. Like all languages, the graphic one is in fact a basic competence necessary for the building and communication of knowledge and therefore becomes a basic component of the scientific method. The research and the exploration of the diverse subjects observable or even simply intuitable, often 
cannot in fact prescind from their graphic representation. Therefore, the research activities of the various disciplines that study visible and invisible subjects and phenomena coincide with their representation, without which it becomes impossible to understand the subjects themselves. For the various disciplines it is therefore necessary to incorporate the tools of graphic representation in order to develop research, especially when it is sufficient to do so through the use of digital tools and technologies.

Although this does not imply a problem for strictly disciplinary research activities, it can instead be an obstacle for interdisciplinary research where the recognition and autonomy of individual disciplines is a necessary condition without which there cannot be interdisciplinarity.

c) Transdisciplinarity and search for disciplinary identity

Talking about Graphic Sciences today implies the adoption of a transdisciplinary approach for at least two reasons: one linked to the intrinsic characteristics and the history of the discipline, the other to its current relations with other disciplines and its international recognisability. The first solicitation to adopt a transdisciplinary approach is linked to the need to retrace the boundaries of a research field, to redefine that peculiar view with which to observe and know the world, collecting the fragments dispersed after the previously hypothesized disciplinary diaspora, which has spread within other disciplinary domains methods, instruments, techniques and skills, to rediscover a peculiar and recognizable disciplinary corpus. The second solicitation is instead linked to the need to place the graphical disciplines in the international scientific panorama. Consider, for example, the difficulties of recognition of these competences in the framework of the ERC sectors - European Research Council - and the need to describe this field of investigation through a sum of its possible components traceable within the different ERC sectors. Although recognizing the limits of the ERC classification and the procedures by which they are defined in relation to research projects previously funded within the same institution, this difficulty in placing graphic sciences within the internationally accepted knowledge classification leads to a rethinking of the disciplinary identity with the aim of becoming more recognizable, visible and able to respond to the demand for interdisciplinary research coming from society.

\section{References}

Abbott Andrew (200 I). Chaos of Disciplines. Chicago: University Chicago Press.

Aldrich John H. et al. (eds). (20 I4). Interdisciplinarity: its role in a discipline-based academy. A report by the Task Force of the American Political Science Association. New York: Oxford University Press.

Campbell Donald T. (1969). Ethnocentrism of Disciplines and the Fish-Scale Model of Omniscience. In Sherif Muzafer, Wood Sherif Carolyn (eds.). Interdisciplinary Relations in the Social Sciences. Chicago: Aldine.

Cardone Vito (20 I 6). Immaginare un'area culturale delle immagini visive. In XY, I ( ), 20 I 6, pp. I2-27.

Cicalò Enrico (2019). Graphic, Visual and Image Sciences. In Luigini Alessandro, Panciroli Chiara (eds.). Img journal $01 / 2019$ Manifesto, pp. 106-II5.

Cicalò Enrico (2020). Exploring graphic sciences. In Cicalò Enrico (eds.). Proceedings of the II International Conference on image and imagination. Berlin/Heidelberg: Springer.

Crawford Elisabeth T., Elisabeth Crawford, Terry Shinn et al. (eds.). (1993). Denationalizing science: the contexts of international scientific practice. Berlin/Heidelberg: Springer.

Cummings Richard J. (1989). The interdisciplinary challenge: Connection and balance. In National Forum, 69. (2), 1989, pp. 2-4.

Gardner Howard (20I5). Cinque chiavi per il futuro. Milano: Feltrinelli.

Gass J. R. (1972). Preface. In Centre for Educational Research and Innovation (Eds.). Interdisciplinarity, pp. 9- I0. Nice: OECD.

Goodlad Sinclair (1979). What Is an Academic Discipline? In Roy Cox (ed.). Cooperation and Choice in Higher Education. London: University of London Teaching Methods Unit.

Eco Umberto (2016). Trattato di semiotica generale. Milano: La nave di Teseo.

Gusdorf G. (1979). Why interdisciplinarity? In Kockelmans Joseph J. (ed.). Interdisciplinarity and Higher Education. University Park: Pennsylvania State University Press, pp. I23-160. 
Huber Ludwig , Shaw Gisela (1992). Towards a New Studium Generale: Some Conclusions. In European Journal of Education, 27, pp. 285-30i.

Kavaloski Vincent C. ( 1979). Interdisciplinary Education and Humanistic Aspiration: A Critical Reflection. In Kockelmans Joseph J. (ed.). Interdisciplinarity and Higher Education. University Park: Pennsylvania State University Press, pp. I23-I60.

Klein Thompson Julie (1990). Interdisciplinarity/History, Theory, and Practice. Detroit:Wayne State University Press.

Kockelmans Joseph J. ( 1979). Why Interdisciplinarity? In Kockelmans Joseph J. (ed.). Interdisciplinarity and Higher Education. University Park: Pennsylvania State University Press, pp. 123-160.

Kuhn Thomas S. (2012). The Structure of Scientific Revolutions. Chicago:University of Chicago Press.

Massironi Manfredo (2002). The psychology of graphic images: Seeing, drawing, communicating. Mahwah, New Jersey: Lawrence Erlbaum Associates.

Miles Leland (1989). Renaissance and Academe. In National Forum, 69: I5- 17.

Milgram Stanley (2017). Interdisciplinary thinking and the small world problem. In Muzafer Sherif and Caroline W. Sherif (eds.) Interdisciplinary Relations in the Social Sciences. Chicago: Aldine, pp. 103-120.

Mitchell William J.T. (20 I 8). Scienza delle immagini. Iconologia, cultura visuale ed estetica dei media. Milano: Johan \& Levi.

Morval Monique (1993). La recherche interdisciplinaire: une difficile intégration. In de Gaulejac Vincent, Roy Shirley (eds.). Sociologies cliniques. Paris: Hommes et perspectives.

Nissani Moti (1997). Ten cheers for interdisciplinarity: The case for interdisciplinary knowledge and research. In The social scomandoience journal, 34(2), pp. 201-216.

Piaget Jean (1974). L'épistémologie des relations interdisciplinaires. In Schwarz Richard (ed.). Internationales Jahrbuch für interdisziplinäre Forschung. Vol I. Wissenschaft als interdisziplinäres Problem. Berlin-New York: De Gruyter, pp. I54- 171.

Snow Charles P. (2012). The Two Cultures. London: Cambridge University Press.

Stichweh Rudolf (200 I). History of Scientific Disciplines. In N.J. Smelser, P.B. Baltes (eds). International Encyclopedia of the Social \& Behavioral Sciences, 20, pp. 3727-31. Amsterdam: Pergamon.

Suzuki Kenjiro (2002). Activities of the Japan society for graphic science - research and education. In J. Geometry Graphics, 6(2), 2002, pp. $221-229$

\section{Author}

Enrico Cicalò, Università degli Studi di Sassari, encic@uniss.it

To cite this chapter. Cicalò Enrico (2020). Connessioni tra saperi: disciplinarietà, interdisciplinarietà e transdisciplinarietà delle scienze grafiche/

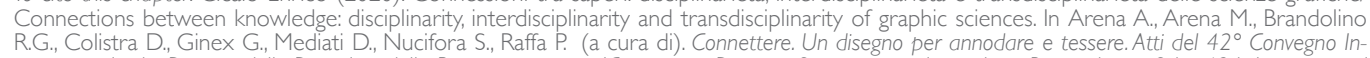
ternazionale dei Docenti delle Discipline della Rappresentazione/Connecting. Drawing for weaving relationships. Proceedings of the 42 th International Conference of Representation Disciplines Teachers. Milano: FrancoAngeli, pp. 316-337. 